Portland State University

PDXScholar

6-1-1968

\title{
A simple engobe developed for general studio use for wet and leather hard clay which may be adjusted with only minor changes to fit bone dry and bisque ware
}

Rose Marie Strassel

Portland State University

Follow this and additional works at: https://pdxscholar.library.pdx.edu/open_access_etds Let us know how access to this document benefits you.

\section{Recommended Citation}

Strassel, Rose Marie, "A simple engobe developed for general studio use for wet and leather hard clay which may be adjusted with only minor changes to fit bone dry and bisque ware" (1968). Dissertations and Theses. Paper 496.

https://doi.org/10.15760/etd.496

This Thesis is brought to you for free and open access. It has been accepted for inclusion in Dissertations and Theses by an authorized administrator of PDXScholar. Please contact us if we can make this document more accessible: pdxscholar@pdx.edu. 
ABSTRACT OF THESIS IN CERAMICS FOR PAPER RECARDING THE

DEVETOPHENT OF ENGOBES FOR CONE SIX CLAY BODIES

BI

S1ater Rose Marie Strassel

(Sivter M. Margaret Il1zaboth Strassel)

Abstract approved by

Thesis/adviser 


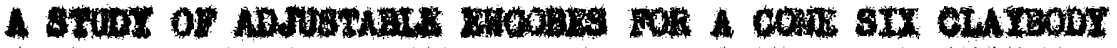

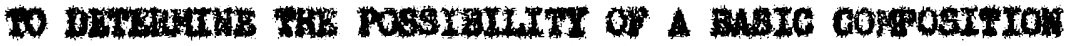

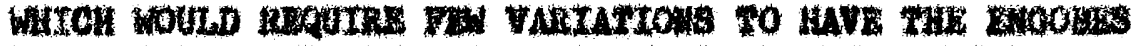

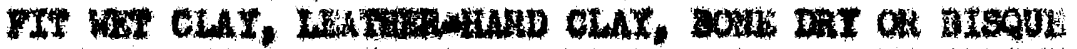

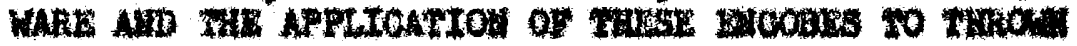

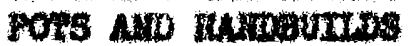


Poonday

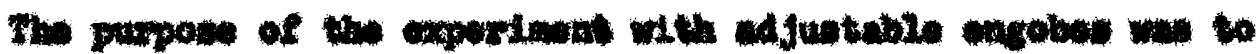

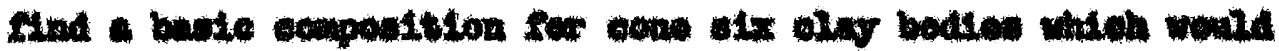

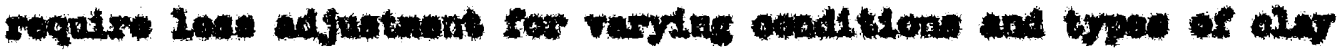

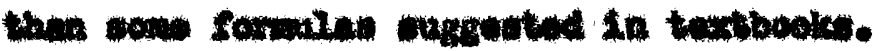

\section{Hockoves}

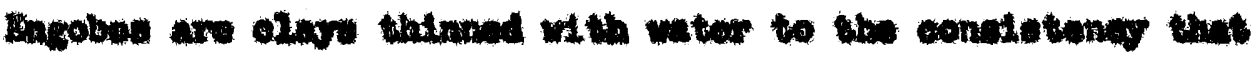

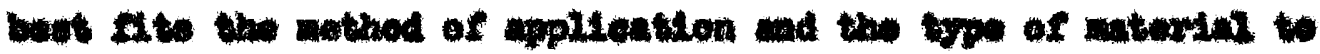

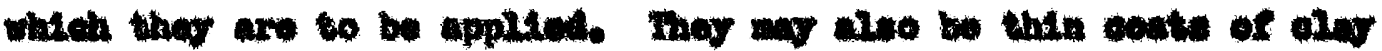

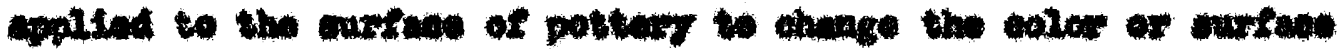

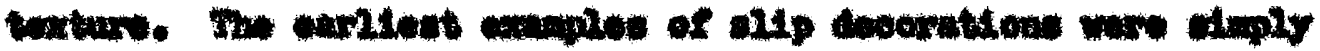

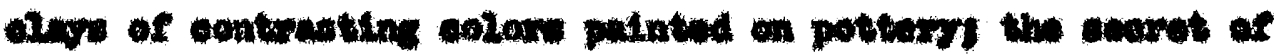

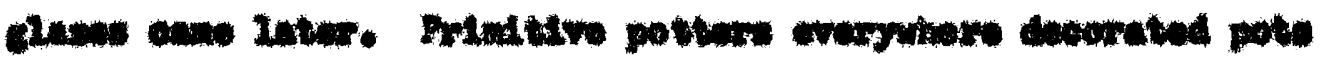

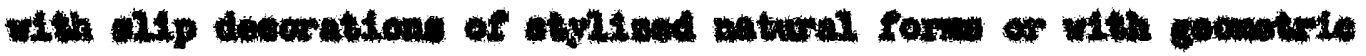
puttarase.

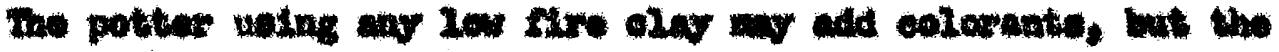

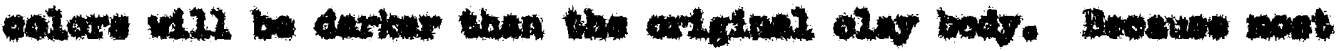

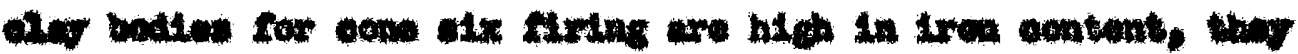

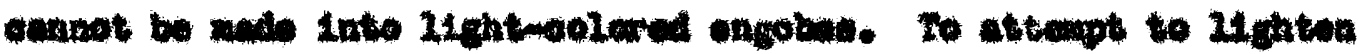

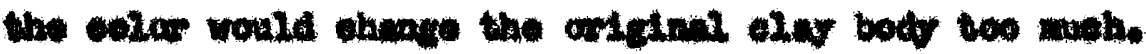

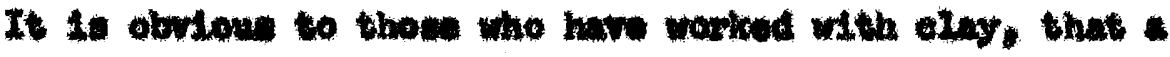

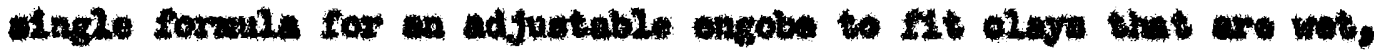

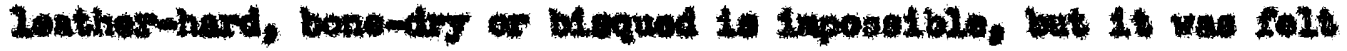

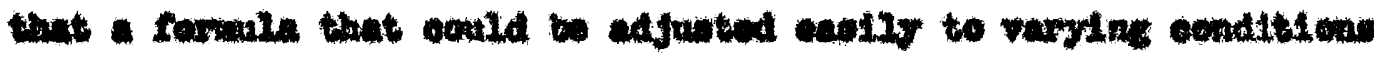




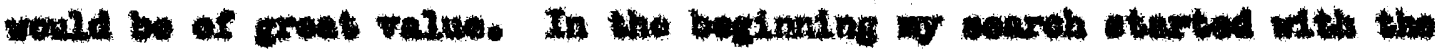

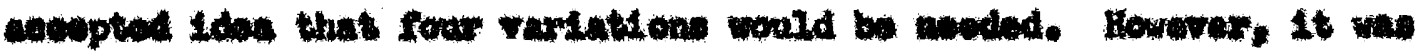

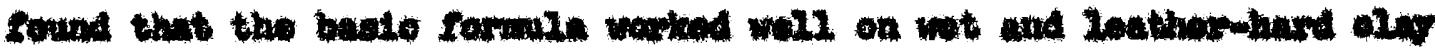
and of cagunting the anounte of balin and bell olw vithen the rave

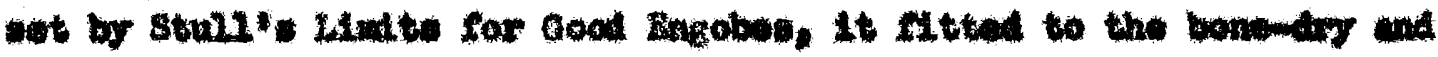
biogue as well.

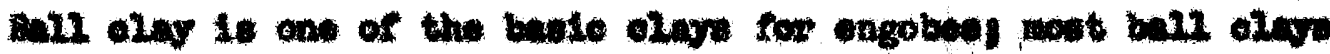

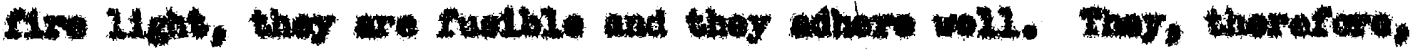

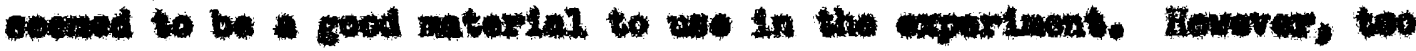

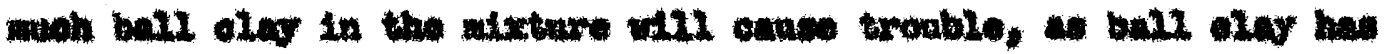

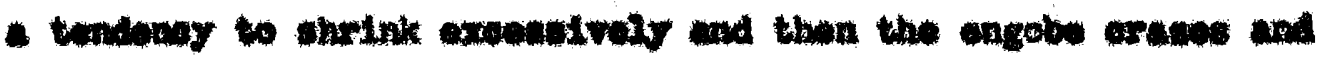

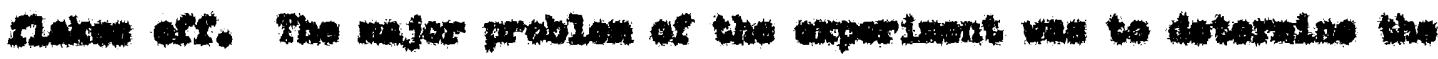
poper axount of bill olay to wes.

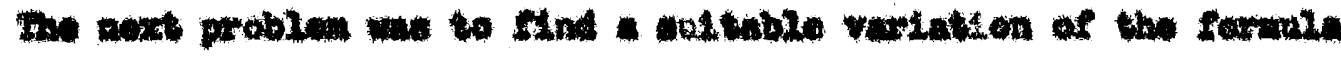

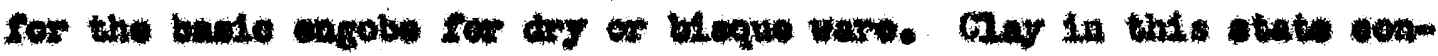

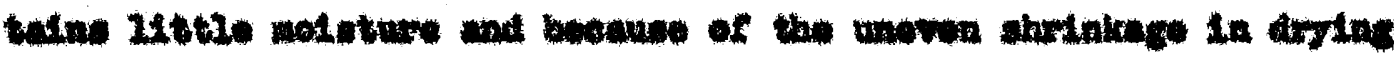

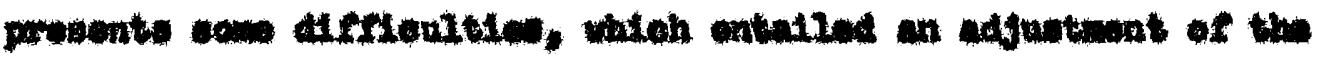

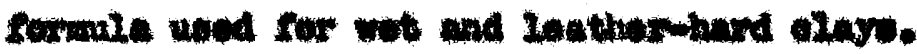

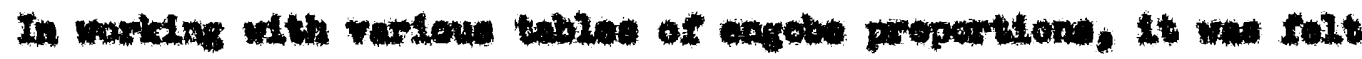

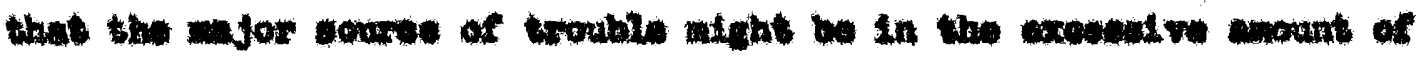

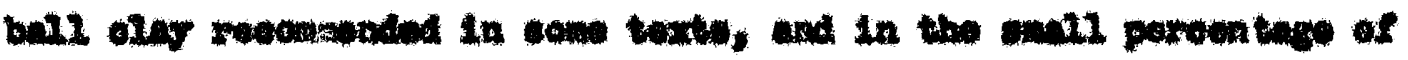

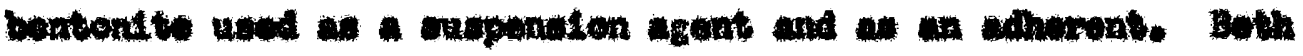

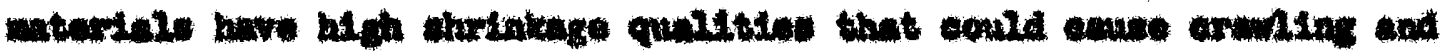

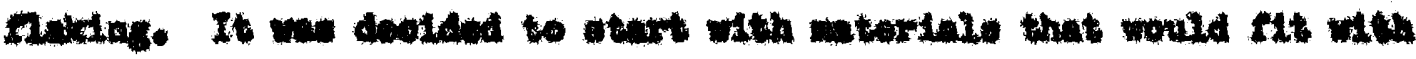

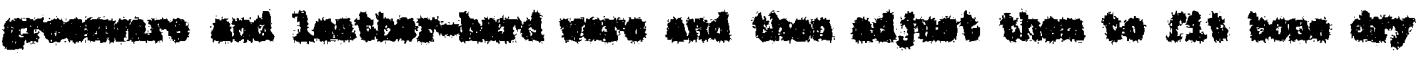

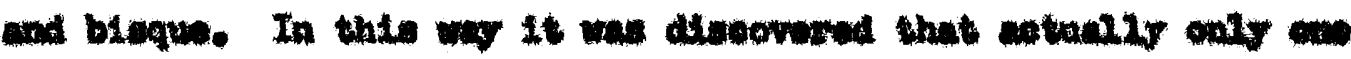

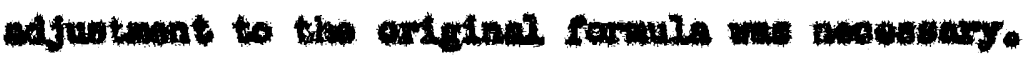




\section{A Bomux or movums}

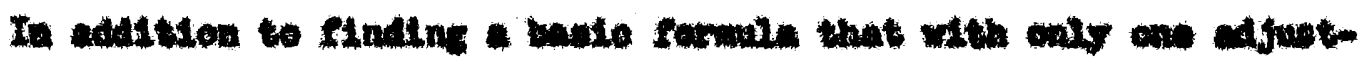

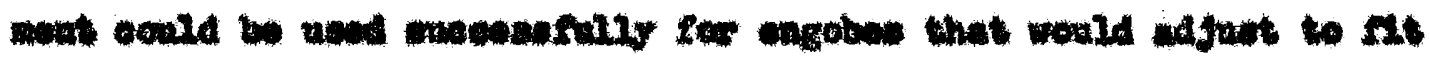

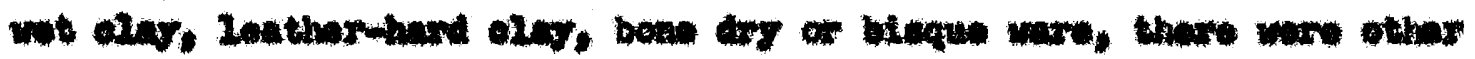

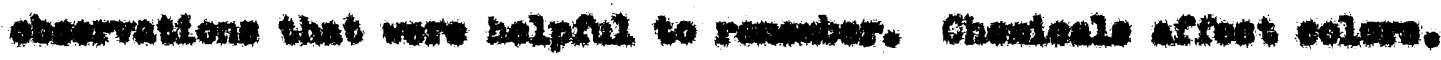

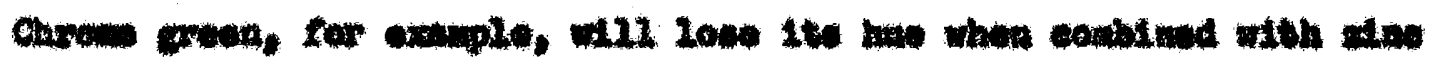

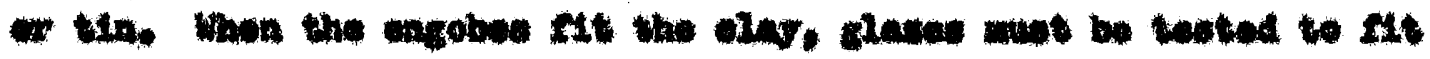

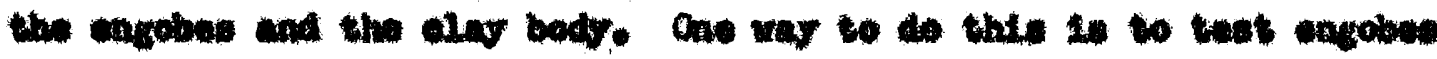

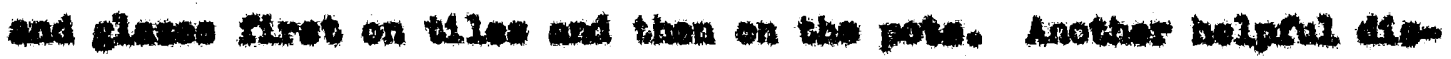

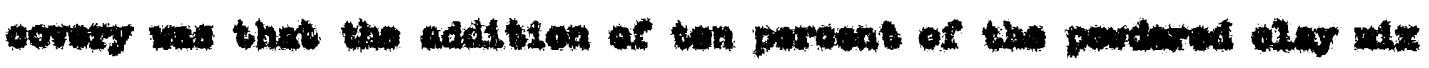

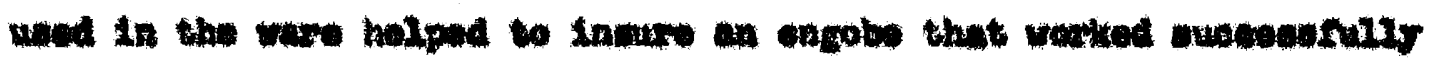

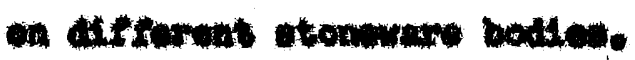


A SIMPLE ENCOEE DEVELOPED FOR GENERAL STUDIO

USE FOR WET AND IEATHER HARD CIAY

WHICH MAY BE ADJUSTED WITH

ONLY MITHOR CHANOES TO

FIT BONE DRY AND

BISQUE WARE

BI

SISTER ROSE MARIE STRASSEL

\author{
4 \\ THFSIs \\ SUBNITTED TO \\ PORTLAND STATE COLLEOA
}

IN PARTIAL FULFILCMONT OF THE

REQUTRERBNTS FOR THE DECRE OF

MASTER OF SCIEHOE OF TEACHTN

JUNE,

1968

PORTLAND STATE COLLEGE

LIBRARY 
APPROVED

TheSIS ALVISOR
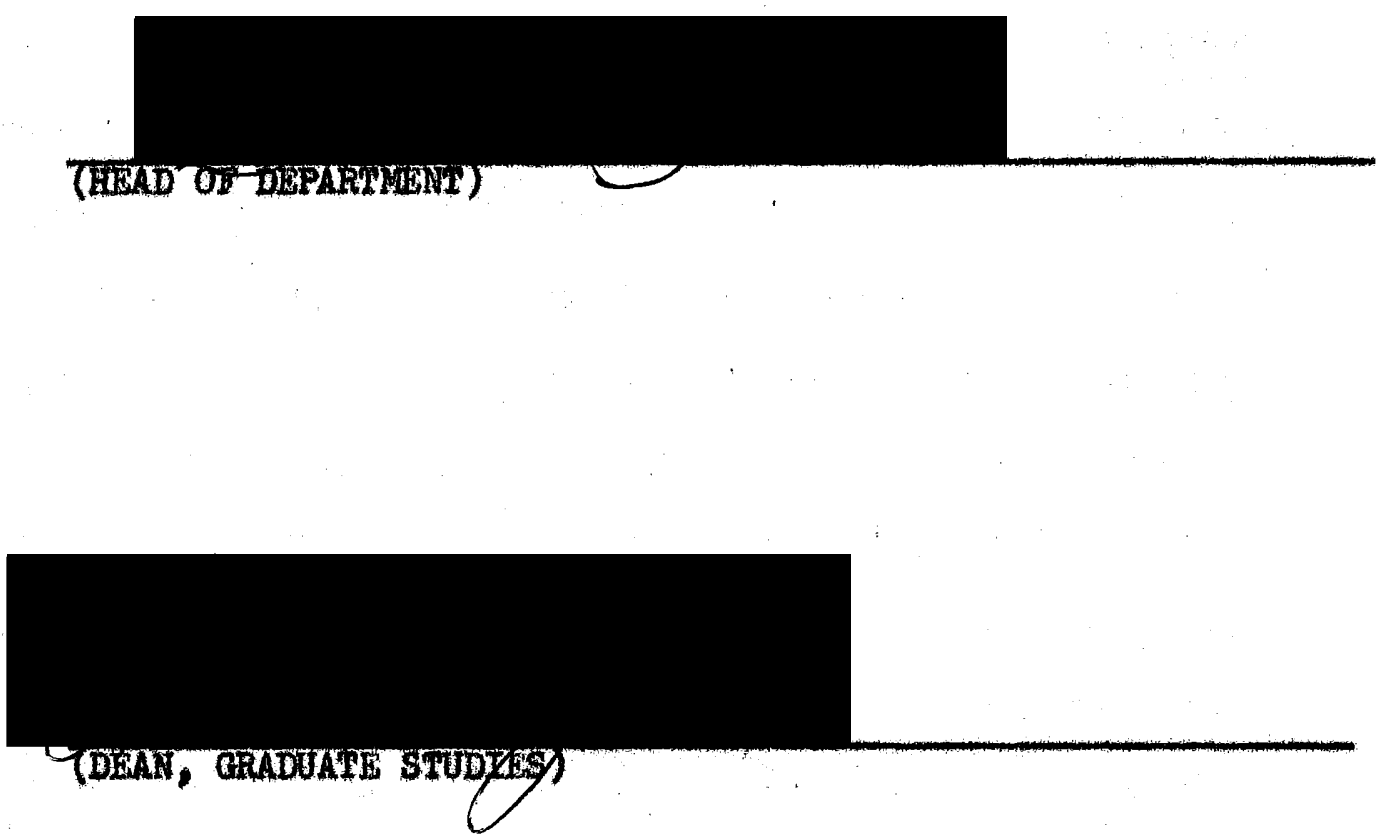

DATE THESIS IS PRESENTED:

Aprit 30, 1968

TYPED BI: Mre. D. Fogarty 


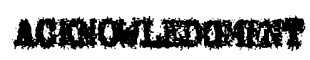

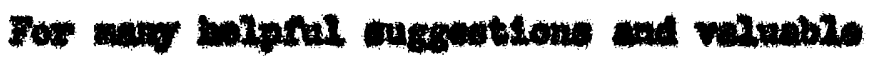

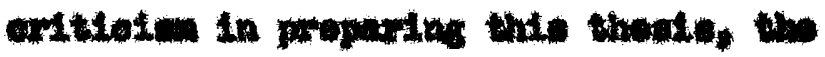

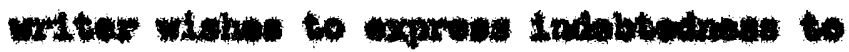

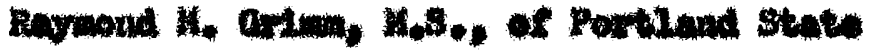
collezi. Parvind, Ongm. 
PRERACE ............................... 1

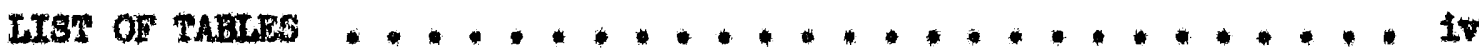
IIST OF ILUUSTRACIONS .................... v CIAPTER

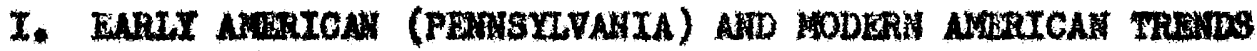

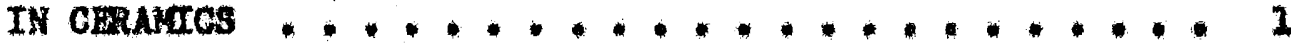

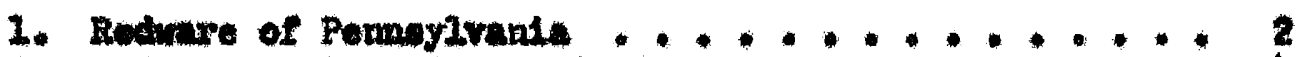

2. Hodora Amortaen Irunds in Pottery ..........

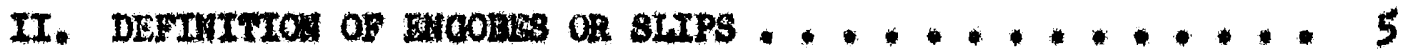

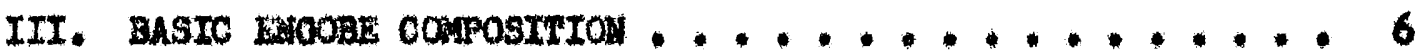

2. Proliminary Work in Clay and Engobe .......66

2. Thoory of Amorint of Bell clug ............ 7

3. S1mple engobea ....................... 7

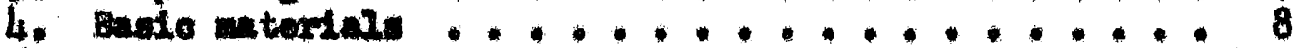

5. Diseovery of a elmplified prosedure ....... 8-9

6. Mothed for dxiag an engove ......... 9-10

7. Difference between an ongobe and glave....... 11

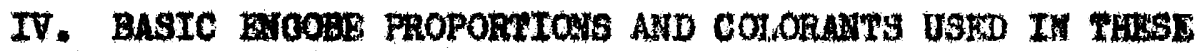

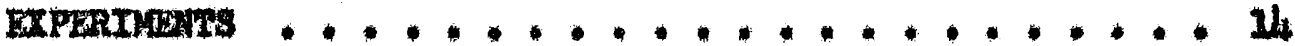

1. Selocted engobe proportion ............. It-15

2. Oxdide oolorente affeoted by temperature ...... 15

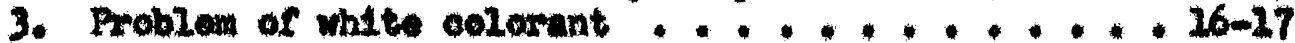

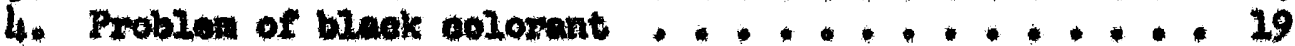

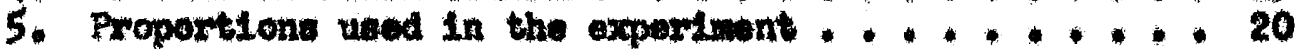

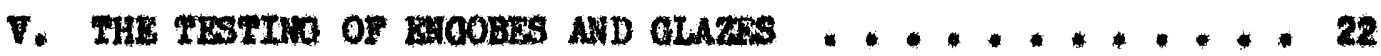

1. Preltadnary toating with Portland State Studite clay . 22

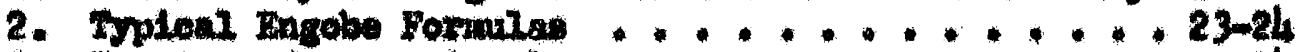

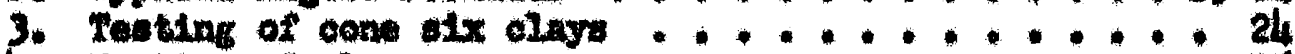

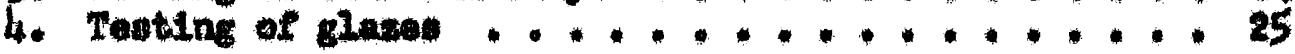

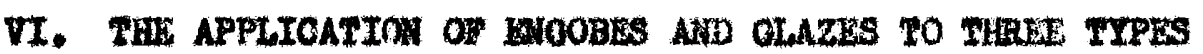

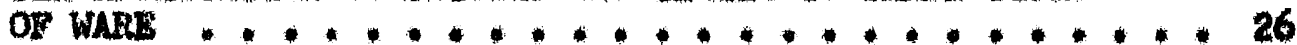

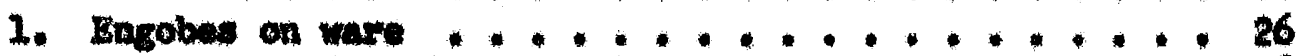

2. Four cono six ocdidation ciases ..........27-28

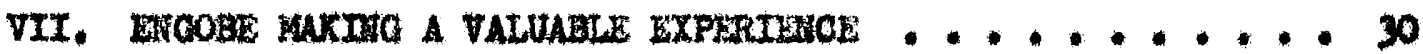

VIII. SETHCT BIBLTOARAPIT ................ 32

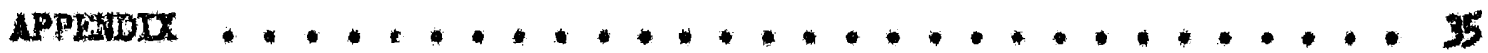

1. Blook engoio formula tor cone ten ...........37

2. Four Cone Ten Reduction Glases ...........38-39 
Thore is in all of us a need for self-expression. The complex and highly meohanized soclety that hes everything on the shole ready for the taking, leaves a vold in the lives of many people, partioularly in urban areas. A doepmrooted noed for individual exgresaion has revived an interest in folk arts of all kinds; among these is pottery-miling. Art elesses almost everyinere give ovidonoe of this Interest.

To make something that is one's om is the longing of any ereative person, even those without particular skills, as well a the eerlous eraftemen. Almost overy facet of Iifo has been toushed by asembly Iine methods of the machine age. The old adage that "there' nothing ner under the oun" does seem to arive some artiats to a kind of rendy to prove 1ts falleey, but for the most part, the potter works at his ant and 1gnores the fads that come and go. Ho obaerves the world around him, tolls at his oraft, inproves hte akille, and one day insplired by a groet ldea and halped by hte expertenee, he expresses it to his orm satisfaction in a now way. From craftemen before hin he learned to ube his tools and to perfoct his teohniques and then the spark of his creative aplrit enkindles the inort mattar. To be ereative and original is bat the beginning, the real artist has talent and has developed his icili.

Perhaps the term, "folk art" is not apt for present day coramios, but the freah charm and honesty of such work is otill worth stariving for. It takes joare to doviop as an individual, and to break ardy from the plentiude of vienal expression imposed on modern sootety. 
to exprese a new Idea. Many do not reach the height of individual work, they come to terms with the demands of the public, who "Mmor what they want". It takes courage to break out a new form to whuck off the safe; to plunge into the unknorm, and have aufficient conHidense to express oneself in a different way. Surfeited, affuent twentieth century people often have nothing to exprese.

Todey disooming individuals, who colleot oarly American pottory, par partioular attention to the alip ware which brightenad the often drab homes of the enriy settlers. Perhaps a moblie people conetantly exposed to the "newest nem", experience a nogtalgia for the past. The simplicity of the lives of the early settlers did not dull their sense for color, which was so often delightfully used in natve, highly-decorated alp ware. A paper on engobes must pay tribute to the okill and honeat expression of these oarly Amexiean artists. In this paper I ahall conflne ny remerks to Penneylvania ip ware. 


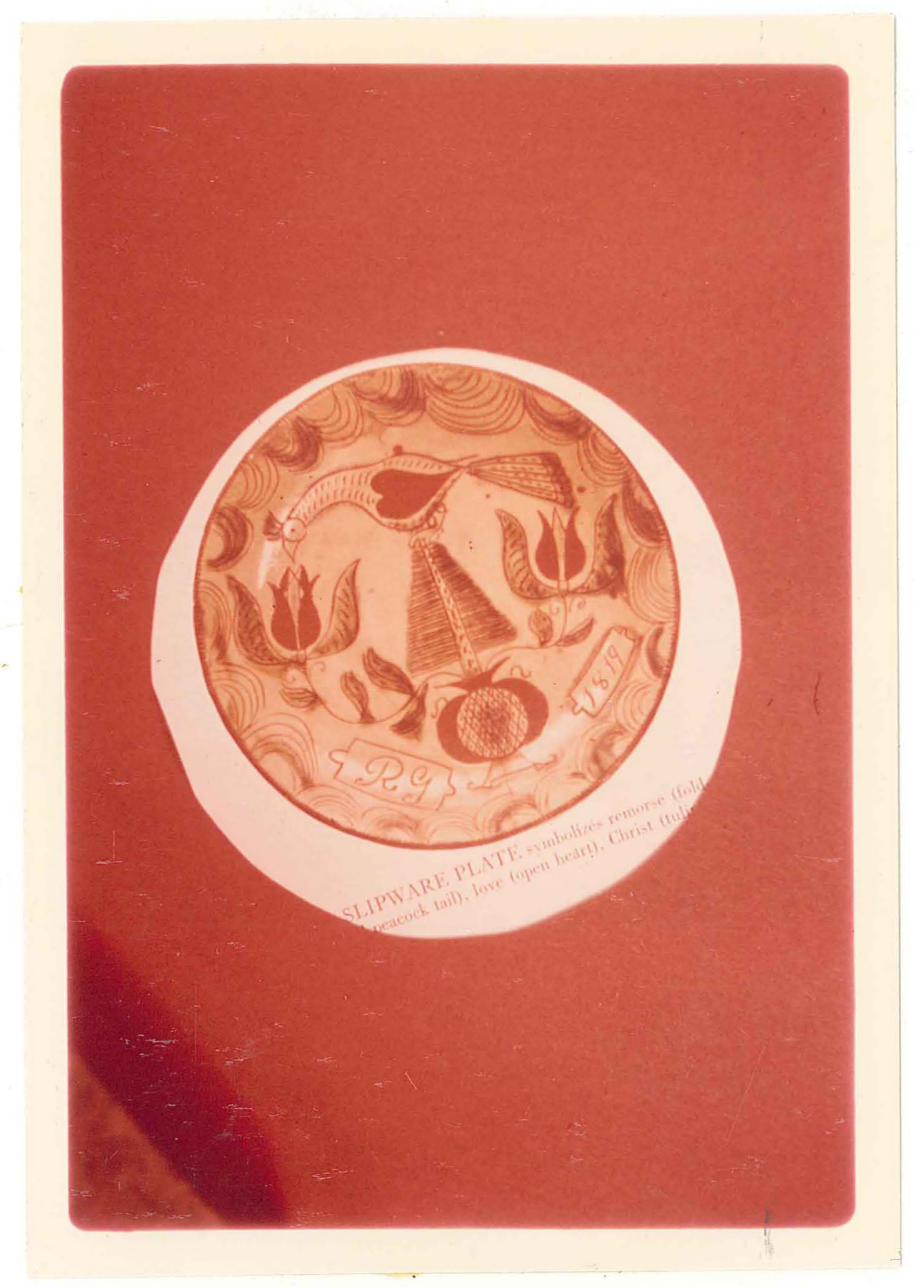

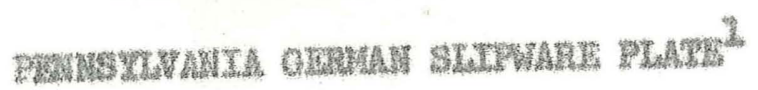

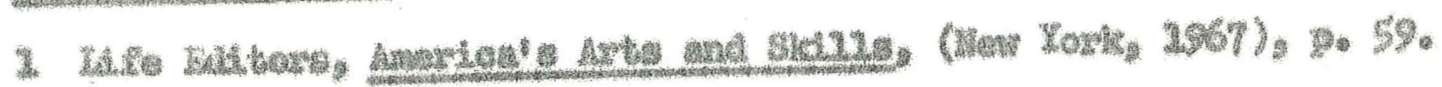




\section{IIST OF TABLES}

Table

1. Stull's Lindtu for Good Ingobos ........9

2. Basic Engob Fonmulas Used in Thts Experimant . I4

3. Convral Quide for Uee of Engobe Colorants.... 18

4. Oxide Proportion Used in the toriment.... 20 
LIST OF ILIUSTRATIONS

\section{IIIustration}

1. Pennsylvania German Sliprere Plate...... Iil

2. Querry T1le Clay P1toher........... 13

3. Engobed 50-50 clay Bowls ........... 21

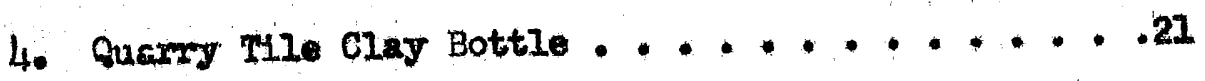

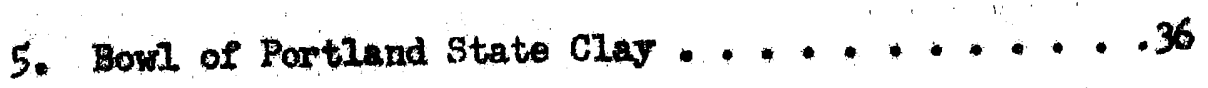




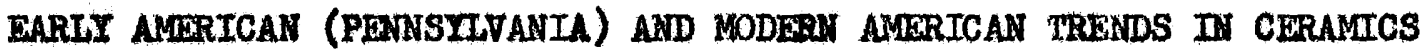

Most of the early Amerioan pottery comes from Pennaylvania, Virginis and the adfolning North Carolina. New England has some, but the folk art with which we are moat faniliar was the work of the early settlens of Pennsylvanim. In that state there is good quality kaolin which was used as a slp, as well as common red olvy. Desigas were trailed on the red clay body by moans of a slip-aup Into which was inserted a quil1. ${ }^{2}$ Py placing a finger on the atr hole in the stepper, the olip trail could be controlled. Nearly every nature form appears in those early pottery decoratione. Birds, animals, Nowers, and fibh wore comonir used, in addition, dota and scrolls were popular. Because the sllp-flow 18 rapid, there was no time far the artist to dally with his design, which wes often nalve, but livass free and alve.

Potters decorated the redrare with alips in splotehes, streaks and with variegated effects. Plain or solid colors were the exception. Iron, manganeat, and oopper were the comen colorants. Blue was rarely used, as cobalt turned black on the red olay. Oceasionaly the whole pot was given a besle color coat of light engobe. On this type of pot, cobalt was used as woll as other dark lips, as they would retaln their coloring over the engobs.

In general the early ware consisted of utilitarian objecte of everydar use, but which nonotheless reflect the oluple tastes

2 A olfp-cup was a eup-11lo deviee to hold Iiquid cley. 
of the new settlers. Todyy collectors weok this old redrare, even though the lead glaze has a tendeney to chip, and the clay body is often too soft. These defects are attributed to the crude materials and to the wood-burning keline that were bard to control and to bring to the proper heat for stonemare.

In tim the arrival of more experionoed potters to the settlement enabled the ploneers to improve both the composition of the clays and the kilne. Finer clay belts were located, and these cambined with the red clay already in use, made a clay body that could withstand high temperature. Stoneware was popular among the German settiers, especially tho slip decorated redrare. Aotually It ia still produced, bat in Iimfted quantities.

Turaing frem early American settlers to the artiots of the twentieth century we find that they can and do enjoy and recreate fron the beanty of the past. In addition, the Inoredible speed of comanication makes it possible to adopt nor ideas almost imadiately and blend them with the old to dovelop non forme.

Today we have in Ameriog, espealally on the West Coast, in addition to Buropean roots, early Ameriean practiee and twentioth century taste, Iresh Japunese influenos. This attraction to the art of the Far-east has groun ince the war. Pottery reflecte these changing times, but it also allows for great freedom of thought and expression. Darlng 1ndividunilists and far-out groups coaxist with schoole which toach basie forms and skills necessary for good oraftamanship in this ancient art.

The simple but very sophisticated taste of the Japanese has influenced pottory making. Simplicity and directness in decoration 
are roplacing the multicelored, detalled style that reflect European traditions. Even some arehitecture shows the effect of of the Orient. Rather austere rooms have areas set apart with dividers, units of adjustable ahelving, or deep window ledges to provide a good setting for cerrmite treasures. Poople with teste scem to have a groring appreetation for good design, wich and subdued color. The interest in ceranie and art shows, or sales, Indicate a renewed esteem for the work of a erafteman rather than for the oheaper, ohoddier faetory-made copy.

Today som cerant ste ween to use color with the same freedom that is common in other flolds even outside of Art. There is room both for the subtlo earth tones of the Japanese shibui stoneware, and for the bright colars. However, in pottery, sheer color seoms to be gatinting over aublety of eolor, provided it 1s color with good design. Good design both of pot and its decoration are ossential. Thi decoration should enhanoe and emphasize the strueture. It is not an ond in 1telef. It must not be addod on like the leing on a oake. There must be in the use of engobes or slips something of the quality of Japanese folk art, if one cen take the liberty of adding to the liet of colors, the bright colors so much onjoyed todiag.

There is In this art a solldity and strength, aimpliatty and directness which axe very refreshing. The colorsaare umally rather somber - black grey, dark brown, dark blues and dark greens belng common -- and ornaments are aimple and abstraet. The whole effect is one of plein sunetional beauty which avolde ostentation, and in that way is quitu defferent from much of the folk art of Europe, which tende to bo gay and colorful and to thow a far grester variety of design."

3 Huge Munsterberg, The Folk Artg of Japan (Vermont, 1959),p.30. 
The dash of Oriental apontaneity in the Japanese acominglycasual application of quiet color to accont one area, has been popular in this countzy. The bright colors traditionel to Duropean pottery have long been an influence. Amertean potters have the opportunity to Integrate the best features of both east and west. 
Engobe and slip are two terma unod quite commonly by people Interested in pottery. However, there seoms to be a need for a precise definition of these term, Coneequentiy, before undertaking a descripttion of the actual revearch enteiled in developIng the now formula, I shall attempt to deftno them in axsot terme. Engobes or silps are natural clays or mixtures of clays, Iluxes, and non-plesties whieh are applied in thin layer on a ceramic body to form a mooth coatlngt pexhapa to cover defecta in the elay body, or to change the celor of the ware. 4 somatimes a distinction is made between engobes and alipss in which case, the engobe is considered complete covering which is oither poured over the pot, or into which 1t is dipped. The alip then is the decorative metertal, when it 18 applied with a bruph, trailed with a arringe, or poured over only a part of the pot. When a glaze has been applited to an engobe, the engobe then mey be called an underalip.

Each type of elay used in an engobe has its om good qualities, a comblnation of several may work suecessfully while one alone w11 not adapt to the particular ware. Only by patient and repeated testing and by keeping orderly notes wall it be possible for the potter to work with aase and accuracy. Acourate records of experimants make it possible to duplicate sucosas and avold a fallure.

4 Gullon W. Parnelee, Ceremic Glases (Chicage, 1948), D. 240. 
An asalgnwent to find an engobe to fit a cone six stoneware clay body mado me realize the difficulties involved in fitting Iightcolored ongobe clays to a dark or red clay body. The ppoblem lies in finding the right proportion in mixing the light-burning olaye so that they will shrink at the same rate as the derk elay body. I did uv prelimary work on engobes the standard way by ueing the preportion table suggented in Parmelee's Ceramic Glarese 5

I did considerable wark with the clays in aotual use in the Portland area in an attampt to find a good light color that would adhere to the dark, cone-8ix body. Basicelly, lightneas of color 1s desired so that colored oxides will show to advantage. Whiteness is obtaIned by combining clays, but they must be oc adjusted that they whrink at the same rate as the dark clay body. In general, keolins provide whiteness and reduce shrinkage, while bell clays add strength, but cave more shrinkage. Most engobes average between forty and seventy percent of these two clays. The proportion which I found mout successful had no more than fifty percent of the two clays. Only ton pereent of the fifty was ball elay. This fact prompted to experiment surther to ascertain whether a set formula could be eatablished, and was the basic ldoa that encouraged me in the thought that 1t might be possible to elininate some of the formulas in the standard tables.

5 R. T. Stull, quoted in Parmelee, p. 248. 


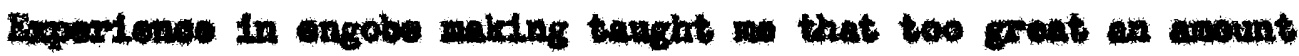
of ball oly oaved axceselve shrinkage, whith in turn reoulted in

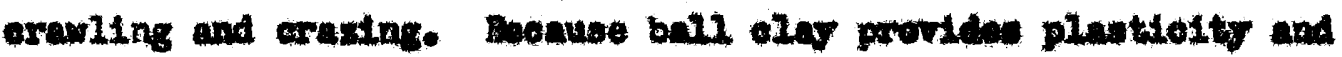

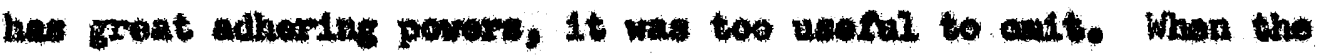
anount of ball oluy was roduead to ton peroent, thore was wo furthow

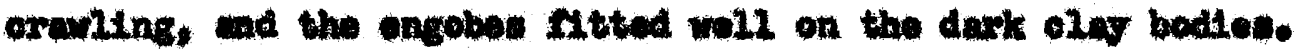

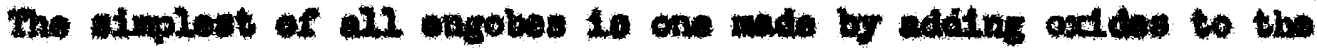

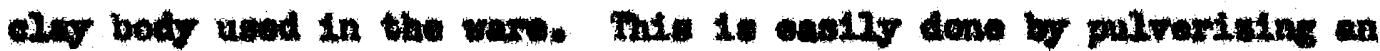

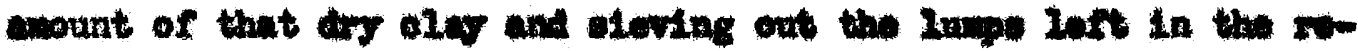

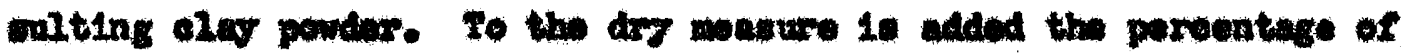
colored oxdde ohoes, arter whioh the two are blovded thorenghly.

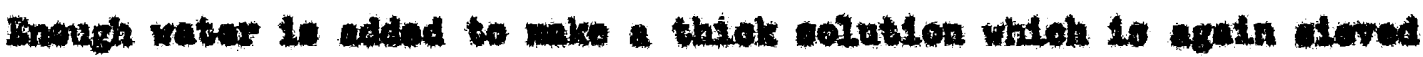

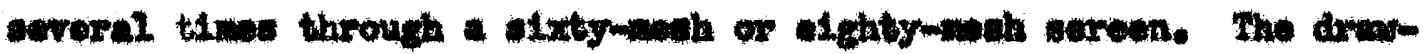

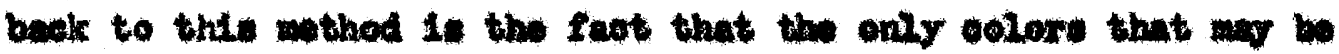
wed most be darker than the oldy of the pot. It is inpoestble to

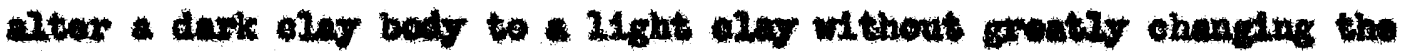

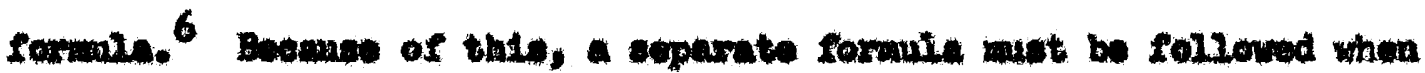
applying unite or 2lghtmealered engobe to red or dark elay. It mat aleo be kept in wind that the engobe winl huve to be applited while the

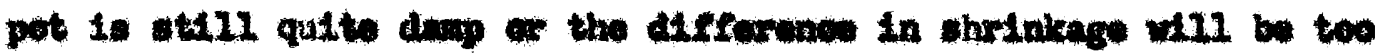
creat to work catisfastorthy.

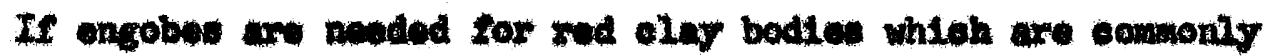
used in the Portinnd area, thay mut be adjuated to shrink the waw

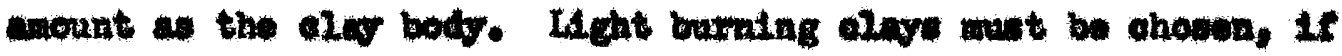
celore are to thow. Sunet angobe formalns are not as neovesary for

6 Dantel Rhodes, Oer and Qlease for the Pottor, (Philudalphis, 2957), p.160. 
mecesanu alips as they are for glazes, but their composition munt -tey within certain 21mite. Because the characteristics of light burning alay are se difforent trom dark clay, it is a matter of testIng to find which combination will fit satisfactorizy. This atep is very important.

\section{Beale Engobe Composition}

The materials used in engobes are utually chosen trom the following basious (1) olage, (2) fluxes, (3) fillers, (4) hardeners, (5) opaciflers, and (6) colorante. 7 the basic proportions for good engobes were chosen from Stuzll. Limits for Good Engobes foumd In Parrelee. Three formulas were listed, those ueed in this paper were choeen from the first list, but locally available materials ware subatituted for the brand names of materiele in Stwuls list shown in trable $I$.

4h tables were adjusted from proportion I chose from Table I, but undere only two stages in the proceas. By experiment I discovered that I could eccomplith the same result with this wach almpler process. The fect that I could find no recer of previous oxporiment in this rogard made my experimeat more meaningful.

Teats on tiles early in this project ahowed that the engobe formula for leather hard clay worked as well on wet olay. AIthough not statod in Table I, but implied, I checked it for acouracy. However, wh find was that the formulas for bons dxy and

7 Rhodes, pp. 160-161. 
bieque ware with slight adjustments, which will be indicated later, could be redueed to one formala.

TABLT I

STUL'S LTMINS FOR GOOD EHOOBDS ${ }^{8}$

\begin{tabular}{|c|c|c|c|}
\hline & $\begin{array}{l}\text { On bisente } \\
\text { hoids }\end{array}$ & $\begin{array}{l}\text { Ga Ieather- } \\
\text { horrd hody }\end{array}$ & $\begin{array}{l}\text { On bone- } \\
\text { Hus bode }\end{array}$ \\
\hline 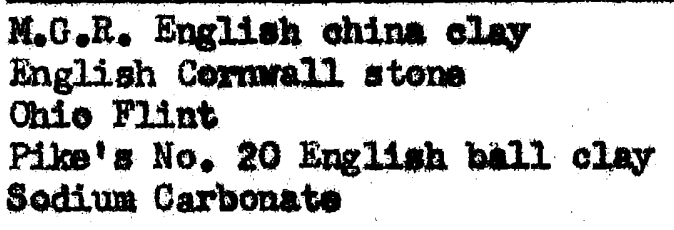 & $\begin{array}{c}15 \%-25 \% \\
25-55 \\
25-50 \\
10 \\
1\end{array}$ & $\begin{array}{c}25 \%-65 \% \\
5-50 \\
0-45 \\
10 \\
1\end{array}$ & $\begin{array}{c}15 \%-25 \% \\
25-55 \\
20-50 \\
10 \\
1\end{array}$ \\
\hline $\begin{array}{l}\text { Merth Carolina kaolin } \\
\text { English Cormall Stone } \\
\text { Ohio Mint } \\
\text { Pike's No, } 20 \text { Englioh ball clay } \\
\text { Sodium Carbonate }\end{array}$ & $\begin{array}{c}15 \%-25 \\
15-55 \\
15-50 \\
10 \\
1\end{array}$ & $\begin{array}{c}558-65 \% \\
5-25 \\
0-30 \\
10 \\
1\end{array}$ & $\begin{array}{l}15 \%-25 \% \\
25-45 \\
25-40 \\
10 \\
1\end{array}$ \\
\hline $\begin{array}{l}\text { Nonth Carolin laolin } \\
\text { Brandywine felopar } \\
\text { Ohto Wlint } \\
\text { Plke's No. } 20 \text { English ball clay } \\
\text { Sodium Carbonato }\end{array}$ & $\begin{array}{c}15 \\
15-258 \\
15-50 \\
10 \\
1\end{array}$ & $\begin{array}{c}55 \%-65 \% \\
5-30 \\
0-30 \\
10 \\
1\end{array}$ & \\
\hline
\end{tabular}

These two sets of proportions remained constant for all the test: with one exception. For all tests carried out on cone six dark elay, ten percent of that clay was ground into powder and added to the engobe; for all tests run on Portland State Clay, ten percent of that clay was added to the formula. This addition was to help assure a good fit of the engobe to the clay body then being used, and was over and above the weight of the batch mixed. For better adhesion to the ware and for toughenling agent, I added one percent of sodiun carbonate to the basic mix and blended all thoroughly. Thio particular formule will be found on Table 23 the proportions are ay own, and will

8 Parmilee, p. 248. 
not be found in any teat oxaotly like this.

The dry keolln or shine clay and ball clay and other materials require careful wolghing and thorough mixing, and if possible, weving through a forty-mech sorsen. This basio mix is then divided Into as many parte as there are to be colored ongobol. To simplity work, the amounts should be kept in round numbere (500 gram, 1000 grems). To each part of the besic $\mathrm{mlx}$ is added the required pencentrage of colored oxdde, this velght is over and above the engobe walght, The dry materials are then theroughly blonded enough water 1. alowly addod to make a rather thick ereavy slip. Several alevinge through a finor soreen (fifty to olxty meoh or finer) will reovit in a we 21 blended engobe ready for use.

Engobes hould be stored in tightly coverved containers in a ereany consiateney. (PIastic cottage cheese containero with their tight fitting tops are just the right sine). All engobes work better after some daya, snoe the chemieals and olys cen dissolvo completely and they apread more onsily as consequenes.

All engob containere should be labeled carefully. Samle 12bola are given belom

Come S1x Blue Engob. for Wet and Ioathor Herd GIa $10 \%$ Quarry THIo added
Cone \$1x Creen Engob for Bone-dry and Bisque Glay 10\% Quarry Tile added

Mext In importanee to the kaolin and ball olv is fint, which is sometimes called a f1Iler. Mlat is non-plastic and conequently redumes ahrinkage. It has the added advantage of improving the whiteness of the engobe, thw helpling the colors when added. Flint also has the property of hardness which helps with the glase fit. 


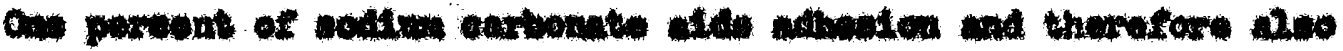

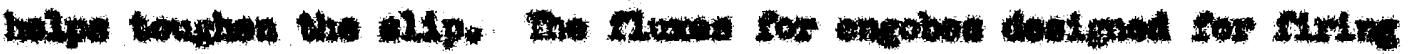

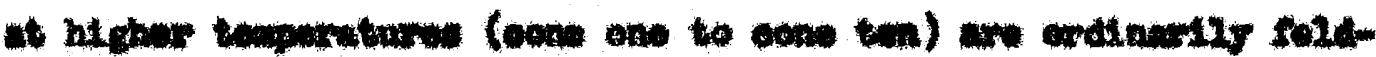

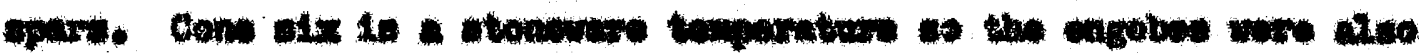

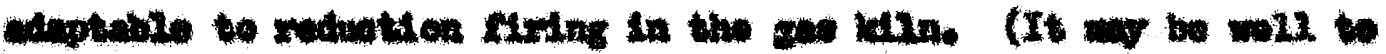

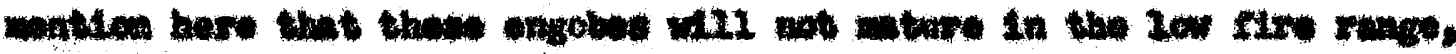

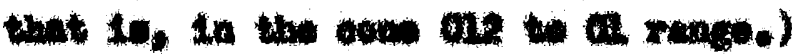

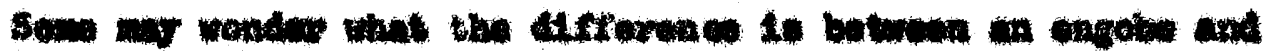

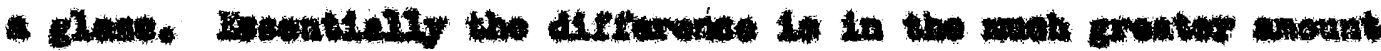

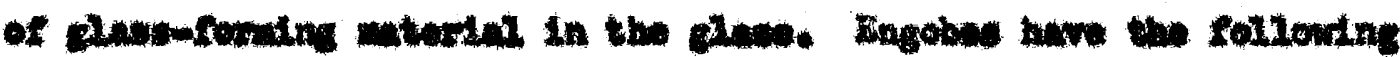

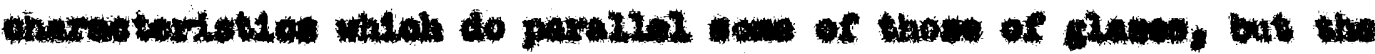

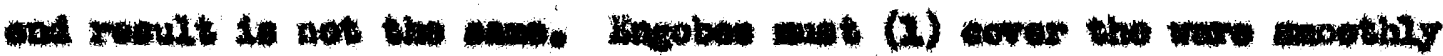

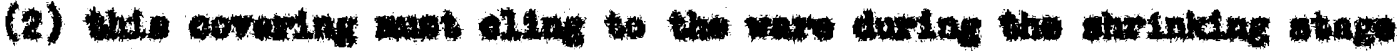

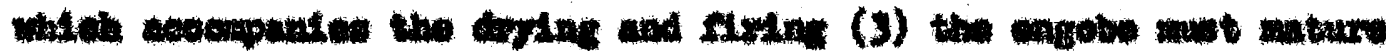

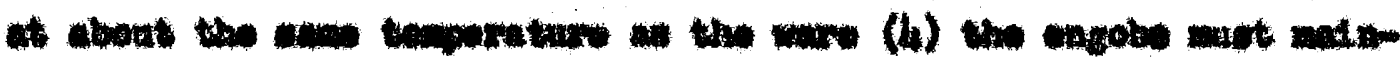

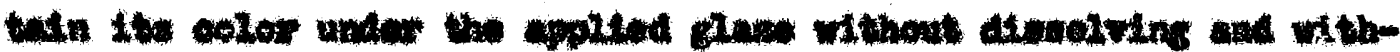

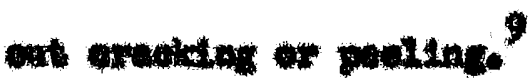

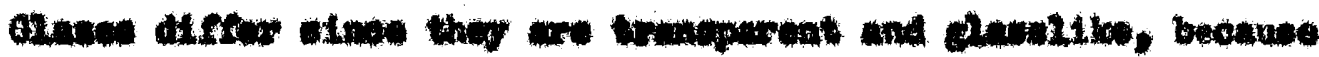

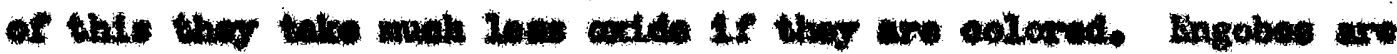

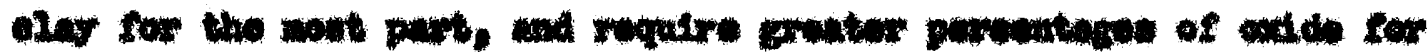

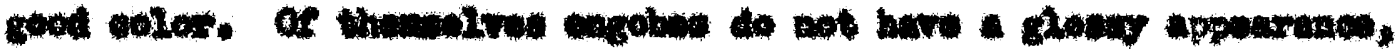

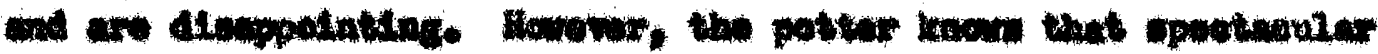

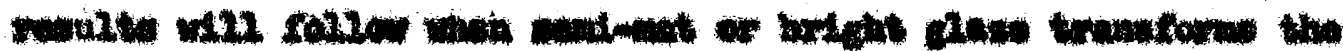

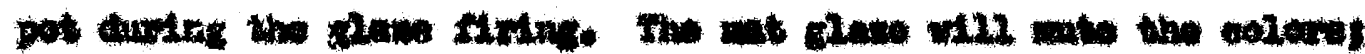

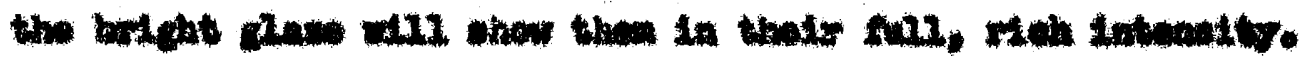

9 vader, p. 160. 
Oniy after the second firing, will the potter be rewarded. A thrill that never wears off will be his each time the k1In it openod on the transformed elay he placed instde. 


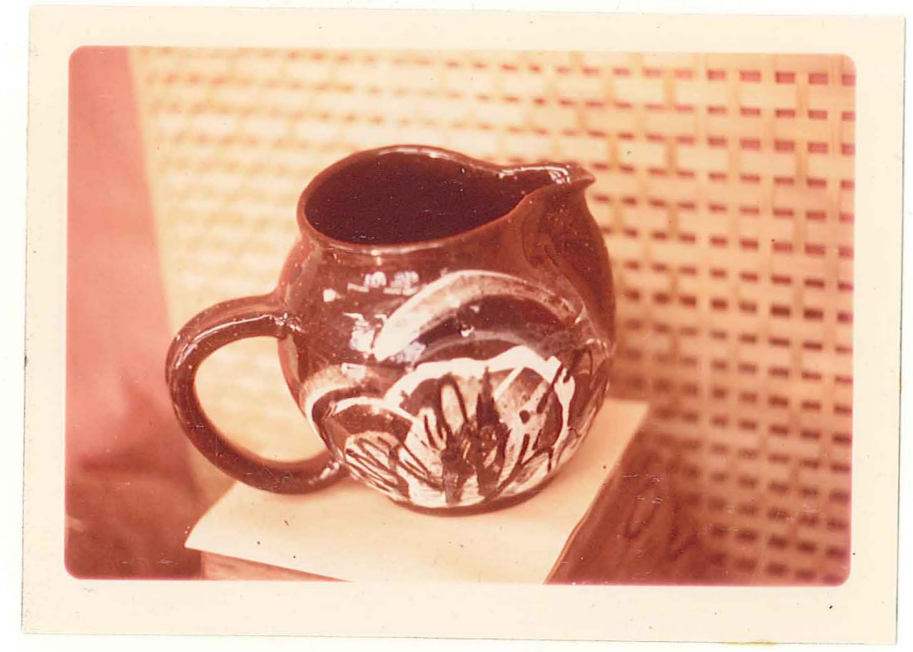

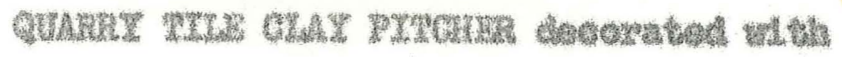

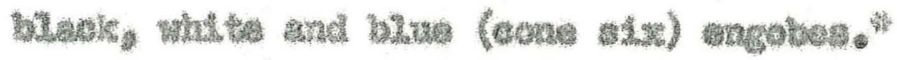

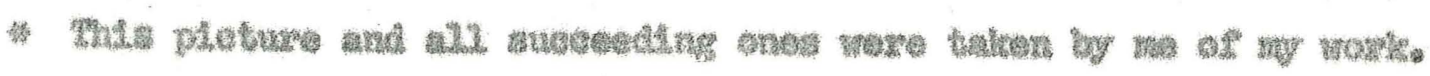


BASIC ENCOBE PROPORTIONS AND THE COLORANTS USED IN THESE EXPERIMLNTS

From early tests based on Stull's list, I found the most aultable proportione for engobes for work to be those listed in Table 2. I narrowed the proportions from the wide range found in texts. I found that the short range was easier to control and keep in balance.

\section{TARLE 2}

BASIC ENCOBE PROPORTIONS USED IN THIS EXPERTMENT

\begin{tabular}{|c|c|c|}
\hline $\begin{array}{l}\text { MATERIALS } \\
\text { USED }\end{array}$ & $\begin{array}{l}\text { WLI AND LEATKIET } \\
\text { EARD ENGOBE }\end{array}$ & $\begin{array}{l}\text { BONE BRY AND } \\
\text { BISOUE GOOOBE }\end{array}$ \\
\hline $\begin{array}{l}\text { Kaolin (China Clay) } \\
\text { Commall Stone Feldopar } \\
\text { Blint } \\
\text { Ball Clay } \\
\text { Sodium Carbonate (soda ash) } \\
\text { Quarry Tile or } 50-50 \text { Clay or } \\
\text { Portland State Clay } \\
\text { Zirconium (for white only) }\end{array}$ & $\begin{array}{l}40 \text { grams } \\
35 \\
25 \\
10 \\
1 \\
10 \\
20-50\end{array}$ & $\begin{array}{l}20 \text { grams } \\
30 \\
30 \\
10 \\
1 \\
10 \\
20-50\end{array}$ \\
\hline
\end{tabular}

Bven with the right proportions, it is important to choose materials for engobes carefully. 10 some of the necessary properties aret

1. Lghtness of color to make the oxides show well.

2. Covering qualities to hide any body dofecto

3. A smooth collotdal consistency, thick enough to hold nonplastic materials in suspension, but thin enough to allow easy application to the vare

4. Adhealve quality, which will make the engobe stick to the ware when it is dry

10 Parmelee, p.243. 
We- Table 2, it was nom, that the olay oontent for the

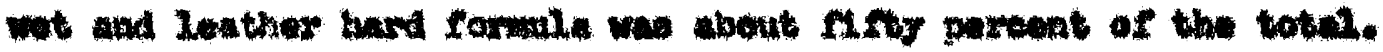

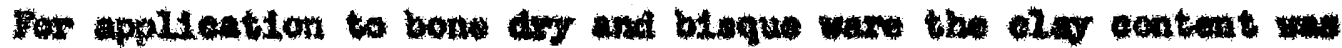

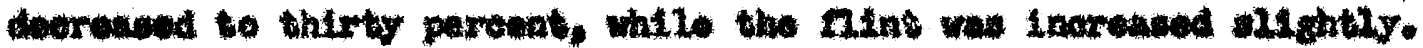

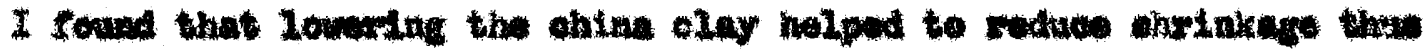

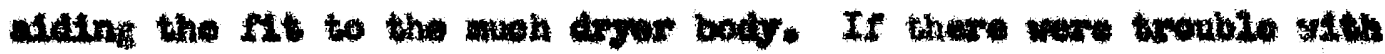

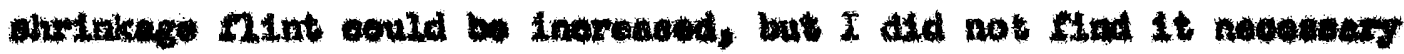
to do thit in tontio.

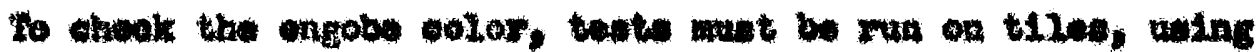

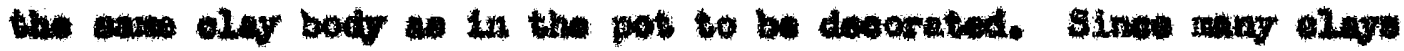

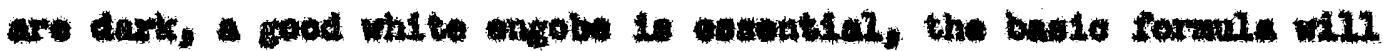

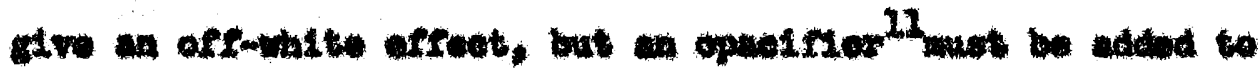

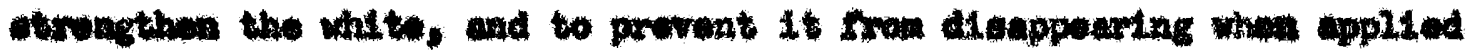

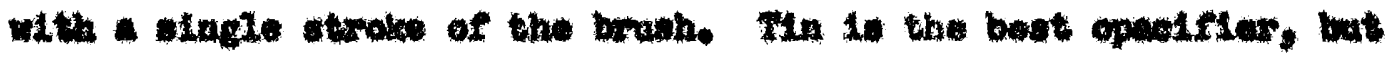

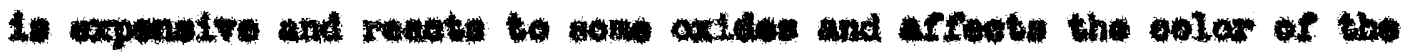

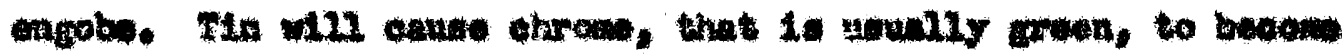

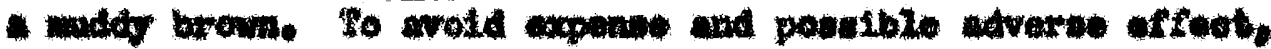

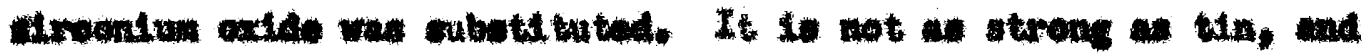

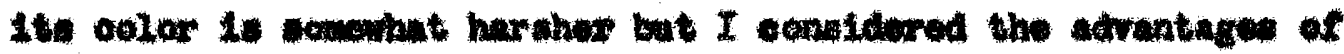

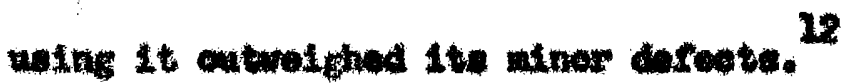

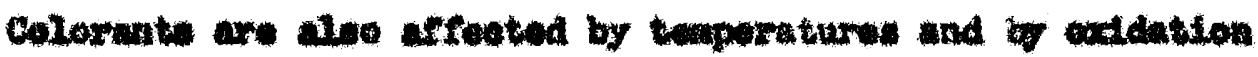

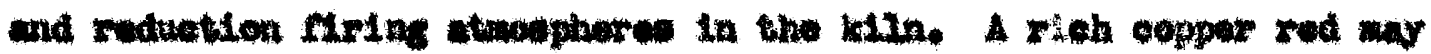

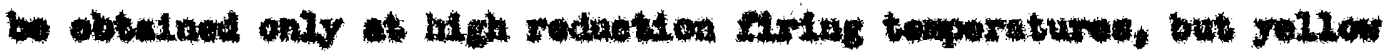

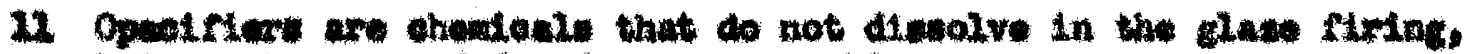
mat ramuin anoponded and co spoent white.

12 Mode, poldh. 
disappears in this temperature. Black, which is not a problea at Iower temperatures, often turng brown or blue at stoneware temperatures depending on other glaze chemicals which may "pull out" the cobalt or manganese used in the black. In reduction firing, chromium axide proved the bost source of green, but the amount used has to be kopt at a minimum since this colorant tends to become heavy and unpleasent. In combination with cobalt and Iron a good blue green reaults, and for general use, I considered this the most pleasing green.

In oxidation firing, copper is probably the best source of green, especially since lead enhances the green colorant. Hany low flre glases contain tin or aincs separately they change chrome green into a bromish grey, together, they sometimes give the chrame green a pinkith brom color. Heing copper axide instead of chrome the problem Is avoided.

In the matter of color the main problem in dealing with dark claye, is to obtain ufficlent miteness in the engobes. It is not as simple a matter to solve this problen as might first appear. I found that thick coats of white engobe either poured on, or applied by dipping, would come through the firing well, but single brush stroke decorations diaspeared in the glaze firing. To discover hou much opacifier was necossary in order to get a good white, atrong enough to be used effectively in elngle brush stroke decorations, I carried out a number of testo.

To avold the expense of tin, and the adverse effects of both tin and zine, I decided to try a method suggested by Carlton Ball, 13

13 Carlton Ball, Decorating Pottery W1th Clay, Slip and Glaze (Columbus, 1967), p. 01 . 


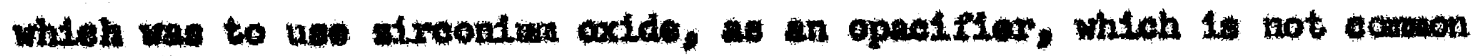
practice. To do this, I dridud ory bateh of engobe into five parts

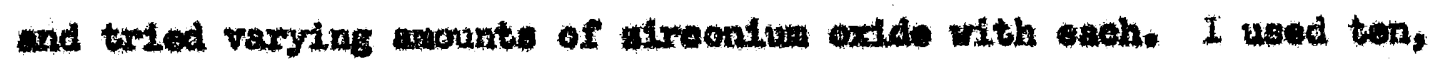

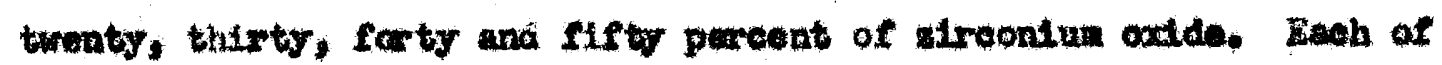

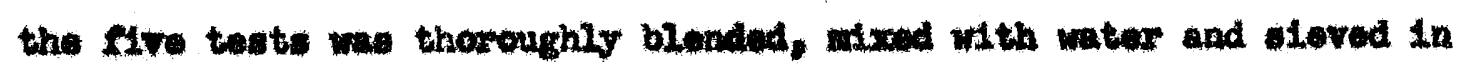
the uoni war. ALI five tonti were applied in vertieal atripe and

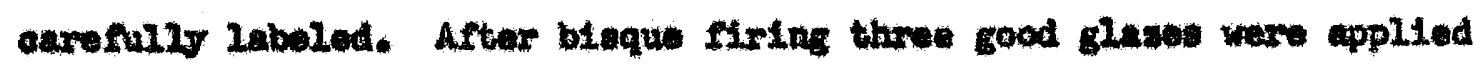

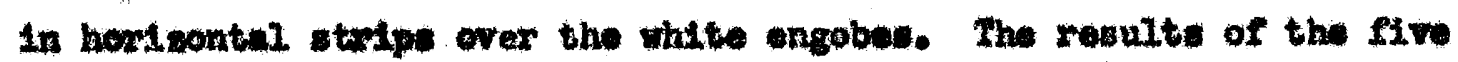

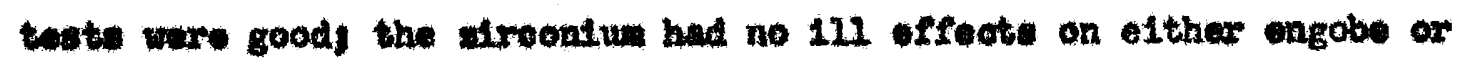

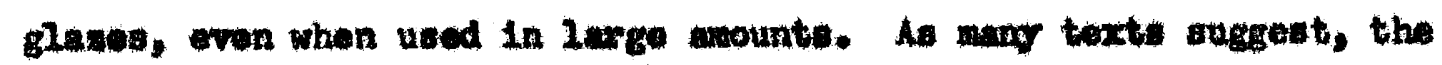

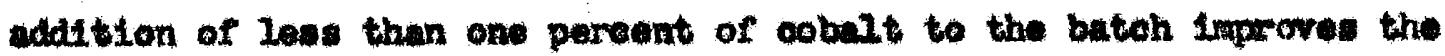
white quality, mach as bluelng improves rinw. 14

In ardar to abtarinin whet paroentage of oxidis I should add to the dry wetght of the base engobe to get the dastred color, I ran

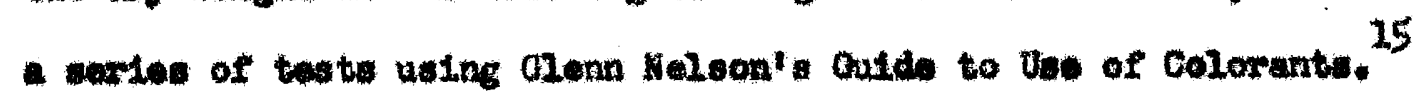

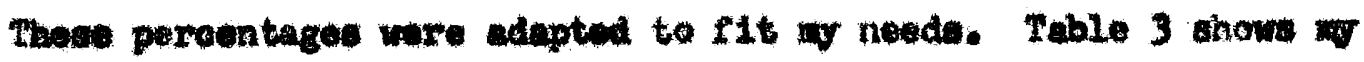
aptetion.

The porcentages of oxide given in Table 3 added to the ary wolght of the bave engobe hould give the eolore indioated. sone caldes in combining with others form a more mbthe color variation. As has been atated previounlJ, al angobes wh colors added chould be tested on tiles before belng applled to pottery. Clay bodtes differ so gratid that reoulte will raxy.

14 Parmeloe, p.266.

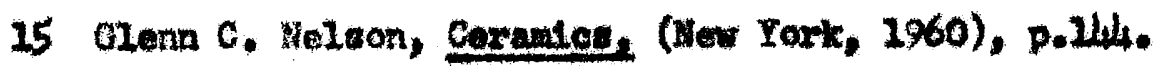




\section{TABLE 3}

GENERAL GUIDE FOR USE OF ENGOBE COLCRANTS

\begin{tabular}{|c|c|c|}
\hline Dacides & Pereent & Color \\
\hline Cobelit Oxde & $2-3$ & Iight to dark blue \\
\hline $\begin{array}{l}\text { Nickel Oxdide } \\
\text { Cobalt oxdide }\end{array}$ & $\left.\begin{array}{l}1-2 \\
2-3\end{array}\right\rangle$ & muted blue \\
\hline $\begin{array}{l}\text { Cobalt oxide } \\
\text { Iron Oxide }\end{array}$ & $\left.\begin{array}{l}2 \\
2\end{array}\right)$ & warsa blue \\
\hline Iron oxide & $10-15$ & Iron brown \\
\hline $\begin{array}{l}\text { Manganewe Dioxdde } \\
\text { (more than } 5 \% \text { may bubblo) }\end{array}$ & 5 & purple browa \\
\hline Rutilo. & $3-5$ & $\tan$ \\
\hline Iron oxide & 2 & $\tan$ \\
\hline Iron (reduction firing) & $2-3$ & green \\
\hline \multicolumn{3}{|c|}{$\begin{array}{l}\text { Copper oxide (oxidation) } 5-8 \\
\text { (above con } 8 \text { copper volatilises, and in roduction turne red) }\end{array}$} \\
\hline $\begin{array}{l}\text { Gobalt oxdde } \\
\text { Iron Oxide } \\
\text { Mianganese Dioxelde }\end{array}$ & $\left.\begin{array}{l}2 \\
8 \\
3\end{array}\right)$ & black \\
\hline \multicolumn{3}{|c|}{$\begin{array}{l}\text { Chrome (oxidation) } \\
\text { (may turn pink if tin is present or gray if gine is present) }\end{array}$} \\
\hline $\begin{array}{l}\text { Black cobalt } \\
\text { Red Iron Oxdide } \\
\text { Chrome Oxide }\end{array}$ & $\frac{1}{\frac{1}{2}}$ & blue grean \\
\hline
\end{tabular}

Sine Poxtland State College has a reduetion kiln, as well a an oxidation $\mathrm{klIn}$, in doing my testing, I found myeelf thinking in terms of both types of firling, even though I was actually using cone six firing, the lowest atoneware teiperature. Most engobes work as well under ather flring, but blaok engobes often show brom or 


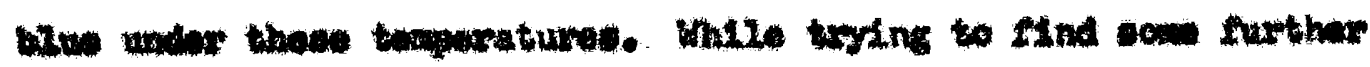

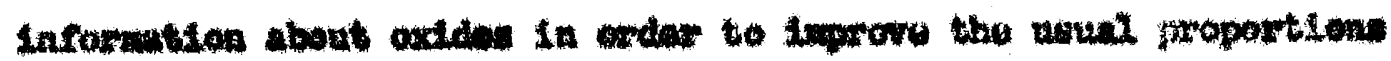

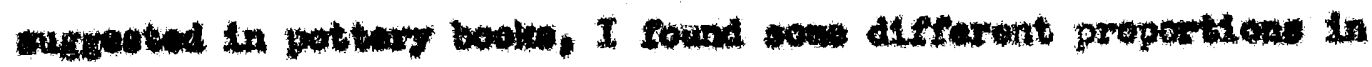

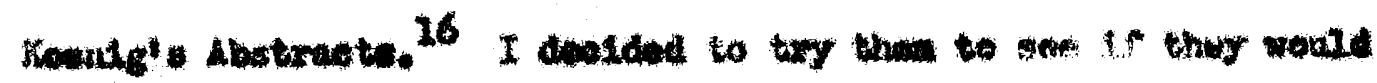

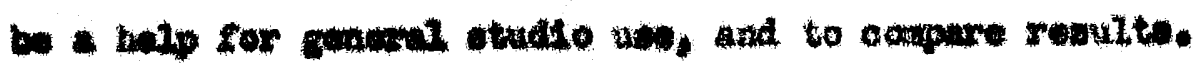

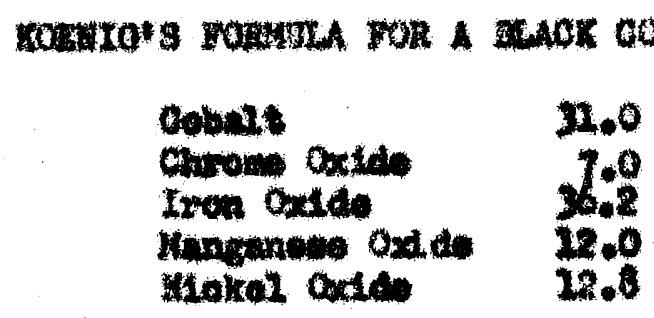

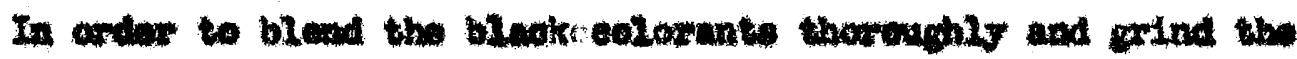

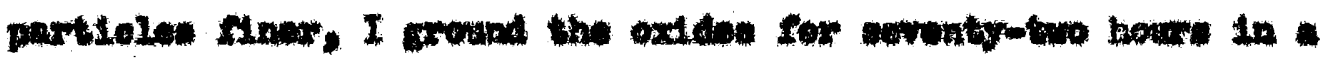

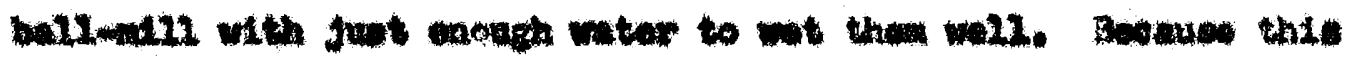

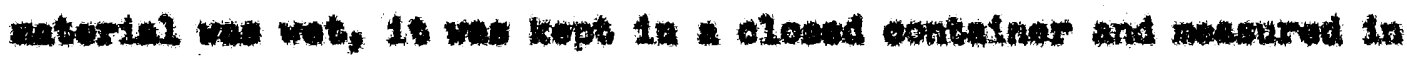

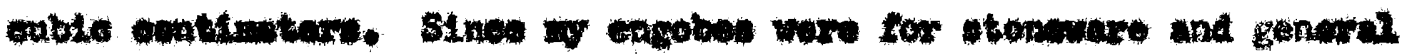

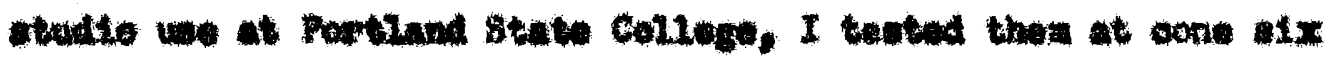

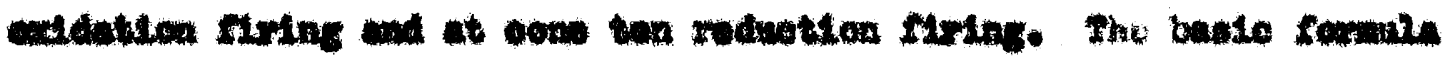

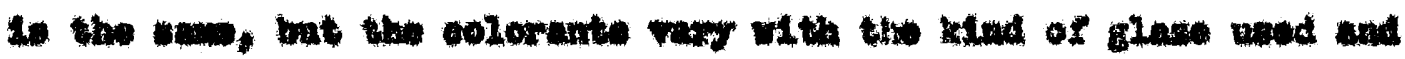

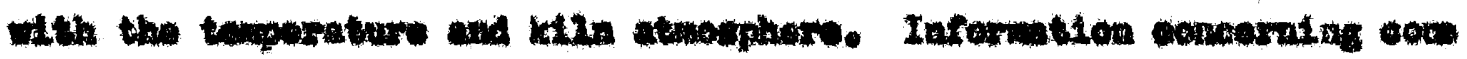

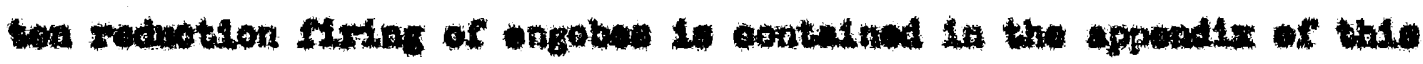
partare

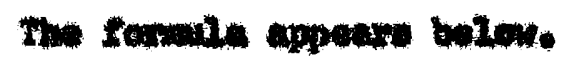

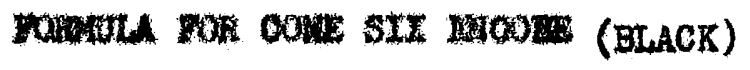

500 bes ongohe

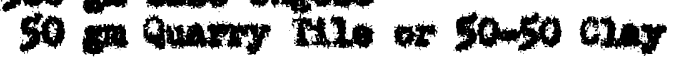

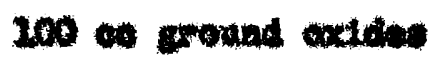

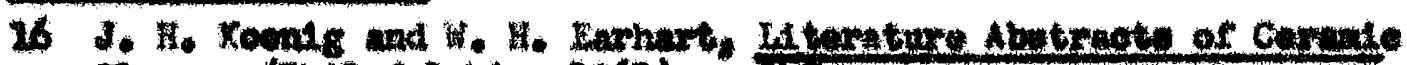

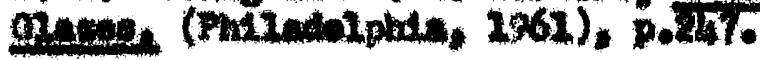


In preliminary testing I used wany colorants, but I made a careful record of angobes using the following proportione. I set a thousand grams as the basis for each color and added the percentagen of oxddes shown in Table 4. The weight of the oxides is over and above the weight of the basic formula selected. To the dry weight of each bateh I added ten percent of the clay used in the body of the ware, over and above the batch velght of the base formula.

\section{TABLE 4}

OXIDE PROPORTIONS USED IN THE IXXPERTMENT

\begin{tabular}{|c|c|c|c|c|c|c|c|}
\hline & $\begin{array}{l}\text { BLDE } \\
\text { GREEN }\end{array}$ & ORERE & BROAN & $\begin{array}{l}\text { IRON } \\
\text { GRAI }\end{array}$ & BLUES & WHITE & BLACK \\
\hline $\begin{array}{l}\text { RED IRON } \\
\text { OXIDE }\end{array}$ & 2 & & & 4 & 2 & & 8 \\
\hline $\begin{array}{l}\text { COBALT } \\
\text { BLUE }\end{array}$ & & 1 & & 2 & $2-3$ & $7(.005$ & \\
\hline $\begin{array}{l}\text { WANGANESE } \\
\text { DIOXIDE }\end{array}$ & & & 5 & & & & 3 \\
\hline $\begin{array}{l}\text { ORROME } \\
\text { OXIDE }\end{array}$ & 1 . & 5 & & & & & \\
\hline $\begin{array}{l}\text { FIRCONIUM } \\
(\mathrm{OPAX})\end{array}$ & & & & & & $10-50$ & \\
\hline $\begin{array}{l}\text { BARIAPED } \\
\text { CLAY }\end{array}$ & & & 25 & & & & \\
\hline $\begin{array}{l}\text { BLACK } \\
\text { COBALT }\end{array}$ & 1 & & & & & & 2 \\
\hline
\end{tabular}

To obtain a good black for reduetton firing, the spectal formale alreudy described was used, and the ball mill procedure was followed. 


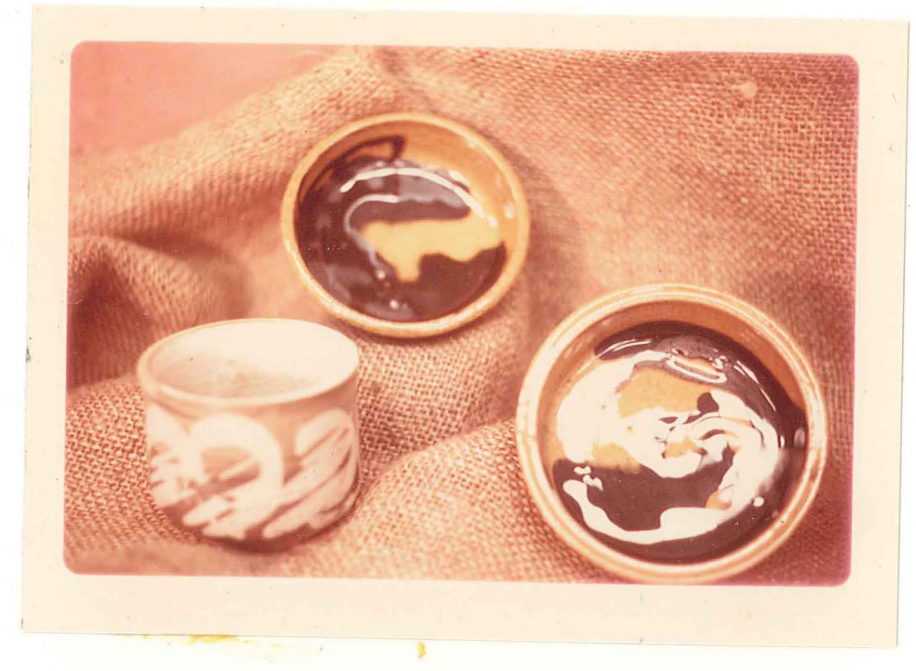

IMGOBED 50-50 CLAY BOWLS, Pitred to cone sist showing seminam and glossy glames.

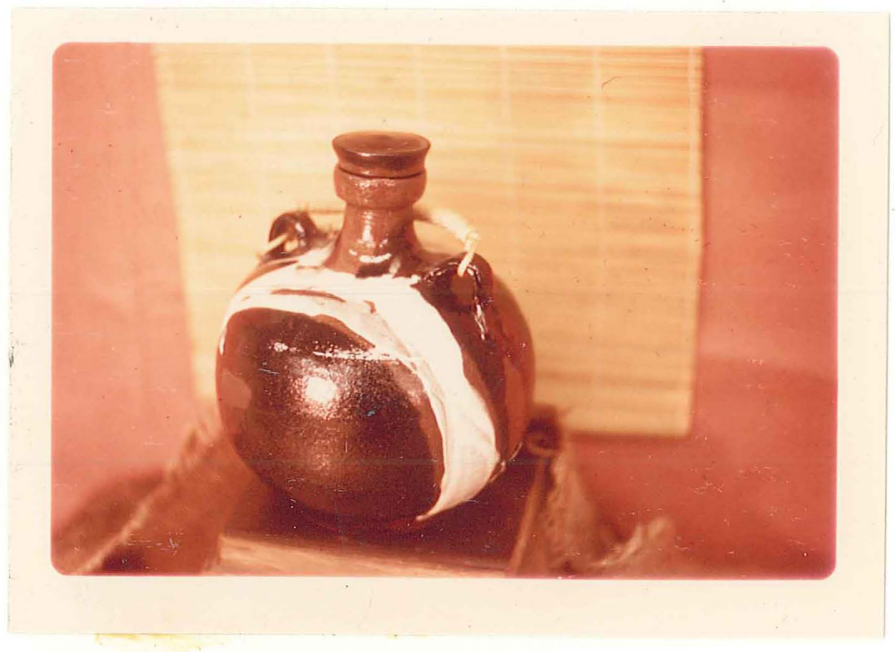

QUARRY TILE CLAY BOTFLS, decorated with blacic and white engobe and glossy glage. 


\section{CHAPTER V}

THE TESTING OF ENGOBES AND GLAZES

To obtain good combination of ongobes and glazes I made a preliminaxy experiment of a line blend on Portland State College Studio clay. Eight tiles about nine inches by nine and nearly half on inch thick were rolled out, five columa were lightly acored in forder to keep the rows of engobes and glazes separated. As 0002 as S Tone tile was stiff enough to accept engobes an inch and a half band (1) of each color was painted from the top to one and half inches from the bottom. The apace was left for 1abels. 17 The process was repeated on a second tile, when it was leather hard, on a third when it was bone ary. When all four tiles were dry, they were bisqueds the fourth tile was then painted with engobes dewigned for bisque firing. All preliminary teste used Portland State Studie clay. The results of the tests were helpful. Not all the engobe colors were good and adjusting was neesseary when dark clar was wed, but in general they showed that the combinations of engobes, glazes and clay body ware good. In addition, this test of colored Ilps shored that the coating of engobes should be fairly thiok.

In later teste the process was simplified because of my discovery that two sets of formulas could be used instead of three. Originally, one formula warked well for wet and leather hard clay, a second was needed for bone dry ware, and a third for blaque ware. By further testing I found that I could adjust the proportions within

17 Ball, p.61. 
the IImits set by Stull, so that one engobe proportion worked for bone dry clay and for bieque ware. This adjustment expedited all the rest of testing. A suggestion of Parmeles ${ }^{18}$ that ball clay be kept to no more than ton percent of the formule also proved partioularly helpful.

Oase the basic engote mix has been made, the batch mor be divided Into amaller amounts for the addition of the oxide colorants. One thousand grams of ary ongobe will malce a genorous amount with which to work. This antount will make over a quart of vet engobe and will If neatly into two quart jare - cottage cheese plastic contalners are eapecially sultable. The colorante are thoroughly blended into the other ary miter1als for all engobes. It is important to Iabel each contadiner Ince the appearance of unfired colors is deseptive.

The proportione 1ipted at the bottem of thia page and at the top of the next page were mong those tested successfully at cono ax in oxddation firing with the addition of ten pereent of the same clay as the body of the ware. In reduction firing ten percent of Portland State Studio clay was subotituted with good results. There are endless combination of colore that may be tried, but I am liating alx difforent colors used in wy tests, which are typical.

Trpian Ingobe Formulas

$$
\begin{aligned}
& \text { Blue Green Engobs } \\
& 1000 \text { grams base engob } \\
& 2 \% \text { red iron oxide } \\
& \text { 1\% black cobalt oxide } \\
& 1 \% \text { chrom oxcld } \\
& 10 \% \text { clay in vere }
\end{aligned}
$$

Green Engobe

1000 rams base engobe $5 \%$ ohrome

1\% cobelt (softens green) 10\% elay in ware

18 Parmelen, p. 244. 

Brom Engobe
1000 gram base ongobe
5\% Manganese Dioxide
$25 \%$ Barnard Clay
(a greater percent of Manganese
ravy bubbla)

\author{
Blue Ingobe \\ 1000 grome base engobe \\ 2 to $3 \%$ cobalt \\ $2 \%$ iron to modify color \\ of Iron)
}
(or use manganese instead

Iron Gray Engobe

1000 grams base engobe

$2 \%$ cobalt oxide

lis iron oxide

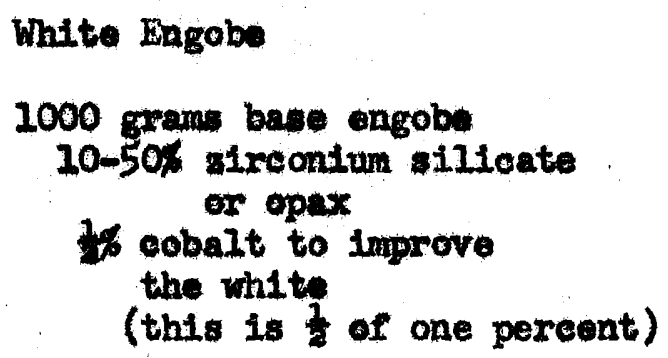

In addition to testing the colore on Portland State Studio olay, It was necessary to run test on other avallable clavs. The mont cuecessful teats wero on the Imaceo clays distributed by the ArtPak Products Company in Portland. These clays are air-noated in the hage Raymond kills in California. This proeess onables the various olaye to be the same in every ohipment, which is no mall faetor in making possible a duplication of ware.

Quarry Tile clay is dark red, pleasant to work with and fires from cone of to cone 8. Three sets of tiles for testing were made; one set with ongobes in the wet and leather hard state, a seoond for boue dry. To show thick and thin application one half of each t11. was covered with a heavy coat of engobe, the other half given a aimple design with a thinner, one brush stroke of engobe. All the tiles were bisqued, then the third sot was engobed, By experinent, I discovered that I had to dampen the bisque tiles first so that the engobe would spread evenly.

The second type of Imaceo clays used is called the 50/50 Mix, 
1t is half Quarry Tile and half off White special Mix. It fires Prom cone 04 to cone 10. For general use it gives a better color, It Ires to light red and responds to the engobes with more pleasing results.

The last clay tested was alend of one half Quarry tile and one half Portiand State Studio Clay. This test was man to try to improve the color of Portland state studio clay for oxdation ilring. The results were not a pleasing in color ab thowe achleved with 50 -50 clat.

The engobe tiles now had to be glaze tested. The first atrip on each tile was left unglazed to show the engobe by ltalf. Dor cone

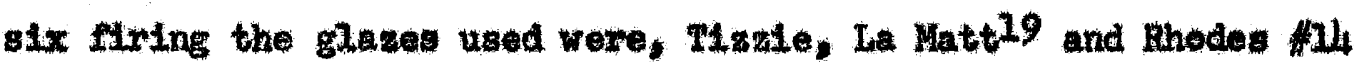
Transparent Colemante. 20 The angobes of the half Quarry Hile and Portland state studio blend were given afferent treatment. The thles were covered with one thick coat of engobe and tested with six glazes at cone six. I trled both mat glazes and glossy glezes. Because the colors on these tiles were Iess interesting then those made with the other clays, no further work was done with this blend.

Completed ceramie pieces of rich quarry nile clay and of 50-50 Wx were quite pleasing. Personal taste would incline some people to choose the muted tones obtained with semi-nat glazes, others to prefer the richer effect resulting from the use of bright glawes. I wefer the glossy glage which tonds to bing out the nleh red brom of the 50-50 Clay! thlle the Quarry H1e Clay becones a deep brown.

19 F. Carlton Ball, Mineographed Notes from College of Arts and Crafts, (no date) Callfomia.

20 Rhodes, 210 . 


\section{CAUPTER VI}

THE APPLICATION OF ENGOBES AND GLAZES TO THFEE TIPES OF WARE

The teste in the previous chapter were to eatablish that the clay of the ongobe would match the clay of the body and to find suitable colors and glases for particular cone six elays. The astuel application of the engobe to the body of a pot is much different from the applloation to the 12 at tile surface. The test tiles show the possibility that engobes can be applied to certaln bodies, but the tiles do not require the teehnique it takes to make the engobes adhere to a pot without eraming or erasing. This chapter w11 report some Indings about applying engobes to wot and loather hard, bone dry and blsque ware and potnt out some techntques aequired through practiee.

Pots that are newly thrown and which require a minimua of trinming may be set aside for an how or two, and then decorated with ongobe, providing that they are ary enough not to collapge from the axtre moisture. Because of the danger of demaing the decoration, It is safer to decorate them after they are trimmed. I found that: (1) Quite heavy cont of ongobe may be rafely applied to a wet or 1eather hard pot. One may powr engobe on, dip the pot, or syringe engobe over areas; (2) After ware is really bone dry, only engobe designed for that state should be used. Bone dry ware mugc have a thinaer engobe decoration compared with that which may be placed on leather hard ware or the oagobe will curl off (3) To apply bisque engobe to a blsqued pot, it is better to dip the pot in water first. 
On damp biaque, the ongobe w1Il apread bettor and a woh anoother affect my be obtained. A completely dry pot sucks the water from the alp instantly, and causes the engobe to chip off the ourface. On biequed ware, brushing is one of the best wars to apply decoration. Thinned engobe may be poured quickly over an area, but thick application with a gyringe is not satisfactory.

There are numorous ways of decorating pettery with engobes much can be learned from the many excellent texts now avallable. Som of the best of these, as well as some of the periodicals to which the leading potters of the country contribute articles, are listed in the bibliography.

Tile teating of engobes and glages, too, is really much simpler than the actual application to a piece of pottory. Apart from all other considerations, color on a test tile seldom looks the seme as a mass of color on a piace of pottery.

I an Including in the following pages of this chapter, the formulas for glazes that I used astlafactorily for cone 6 in oxidation Iring.

TWO BRIGHT OLAZES FOR COHE 6 OXIDATION FIRING

TIZZIE GLAZE e/08 to $\mathrm{c} / 9$ Oxidation 21

$\begin{array}{lr}\text { Flint } & 463 \\ \text { White Lead } & 1500 \\ \text { Kingman Feldspar } & 300 \\ & \\ \text { China Clay } & 420 \\ \text { Nit 313/4 } & 570\end{array}$

Tizzie Giaze is Auid, ohins and enhances the red clays ueed in

21 F. Carlton Ball, Notes. 
these tests. Since there is no tin or alne in the formula, there was no color problem.

Rhodes H4 Transparent Colemanite e/6 Oxidation ${ }^{22}$

$\begin{array}{lr}\text { Kingman feldepar } & 1320 \\ \text { Colemanite } & 522 \\ \text { Barlum Carbonate } & 555 \\ \text { Whiting } & 216 \\ \text { China Olay } & 72 \\ \text { Flint } & 325\end{array}$

This glase is similar to Migxie, but does not require the frit that is necessary for that glase. Again there is nother tin nor sinc. Rhodes suggeste cone four but it works well at cone sx.

TWO SUCCASSFUL SEMI-HAT GLAZES FOR CONE SIX OXIDATTON FIRTHO Neweemb Mat $/ / 04$ to $c / 9$ oxidation 23

$\begin{array}{lr}\text { Lead Carbonate } & 1310 \\ \text { Reldepar } & 840 \\ \text { Grolin } & 1000 \\ \text { Milnt } & 180 \\ \text { zine Oxdde } & 100 \\ \text { Whiting } & 200\end{array}$

This is a dependable mat glawe which allow dark engobes to show if the coat of glase is thin. Because tho is one of the materials it does not work well over chrom oxldo.

$\begin{array}{lr}\text { L.A. Nat o/3 to o/6 Oxidation } \\ \text { Kingmen Feldspar } & 1548 \\ \text { Hint } & 168 \\ \text { Whiting } & 564 \\ \text { Zine } & 258 \\ \text { China Clay } & 462\end{array}$

22 Thodes, p.210.

23 i. Carlton Ball, Notea.

24 Ibid. 
A good somi-transparent mat that allows colors to show in a smited way. Ne1ther of these two sent-mats onhance red clay. However, they could be used in conjunction with wax resist and one of the bright glases. 
Bngobe making is exacting, challenging, and rewarding. It provides exellent training, and increases Insight lato, and appreolation for the complex aldils of the good potter. The atudy of engobes foeveres the attention of the crafteman on form and atruoture. It helps hin derelop a stronger menee of fom. Good decoration enhanees, and beoomes, In sense, part of the whole. It should nover be encrustation.

While the artiat mast not allow tho cecoreting to overwheln the aotarl atwictures while he mat not allor a feeling for cletail to spoll the design of the pot, yet the very making of engobes require much detall and patience. It is expoting to chercies constant care to keep in good oxder the partieular engobes which will match particular olays. Fron the appearanes of ongobes in their contalners, there is no means of teliting their finul oolor, oo proper Inbeling after each test is neceasary.

In addition, the experimonting potter gadulizy acquires a more prectioal imemledge of elay and glases, and the aurprialng chemteal reactions that occur in firing. Engobe making $18 \mathrm{good}$ tratning, and provide excellent oxperience for any potter, even if his later woxk does not require the making of them.

I found engobe work purticularly rerarding, perhaps becuuse I developed a aimpler method of devising proportions than those suggested in pottery texts, and because I acguired some practlcal 
knowledge that I feel would help other student-potters. On paper In words deductions sound rather insignificant, but in the studio they save hours of time ana effort. To restate them: instead of working with three different sets of engobes - one for wet and leather hard clay, a second for bone dry olay, and a third for bisque ware, by adapting basic proportion in Stull's List to a narrowed range, I found that for engobes for bone dry clay, and bisque ware, I could use the ane formula, and thus, eliminate on whole set of tests.

Through experience, I learned that on dark clay the bright glazes onhance both the olay and the engobes. For muted color, the semt-mat glawes will produce a softer effect, but the olay body will not offor a much contrait 28 in the case of the dark elay. The oxido percentage can be inoreased slightly for these glezer, 11 grenter depth of color is desired.

Teachors will find the material detailed in this paper eapecially helpful since most sehools use electrie kflns for wich these engobes were designed. For potters who have gas kilns, the ongobes will adjust readily to that higher temperature and the colors will be still richer because of the reduetion atmosphere.

Students who wish to decorate their pottery, but who have not yet a great deal of experience will atill noed to toat thoroughly, but they will find the suggested olays and engobes harmenious, and as a consequenee, good results should not be too hard to obtain. 
BIBLIOCAAPLI 


\section{A SETECTED BIBLIOCRAPEY}

Ball, F. Cariton. Decorating Potterye Columbus, Ohio, 1967.

Ball, F. Carlton. "Ineised Decoration on Glaze;" Ceramie Honthly, (Decomber, 1966), 12-15.

Bel1, F. Carlton. "Feather Coubing;" Gorenioe Monthly (Harch, 1967), 12-15.

BHIlington, Dora M. The Technique of Pottury, Loidon, 1966.

Muns, Charles. The Potter's Crafte 3rd al, Wew York, 2967.

Clark, Kennoth. Practicel Pottery and Cerames, New York, 1964.

Colson, Mrank A. "Oxdides and Wax-Resist Decoration," Caramice Monthily, 15 (Pobruary, 2067), 20-23.

Eogle, Joanna. "Torao Hara," Creft Horizons, XXV (JuIy, August 1965), 32-33.

Bwing, EIlen. "Pacifle Stoneware," Coramies Monthly, 25 (October, 1967), 27-29

Hockman, Albert W. "Pennoylvania SIIp Ware;": Keramie Studie, 24 (Mareh, 1922), 208-209.

Kenny, Jokn B. Caramic Design. Philedelphia, 1965.

Koonig, J. H. and W. H. Earhart, Ifterature Aloutracts of Caramie Glazes, Philadelphia: 1951.

Kretsinger, Mary. "Try Mishima for Docorating," Ceramics Monthly, 15 (January, 1967), 26-27.

Lfe Editors, America's Arts and Sdille. Nem York, 1967, p.59.

Mokinzey, Doneld, et 2l. "Ceranics Todey," Craft Horizons, XVII

(November, December, 1966), 10-30.

Nelson, Glenn C. Coramies. New Iork, 1960. 
Neleon, Gienn. "Stalhane of Greden," Craft Herizome, XIII (March, April, 1960), 10-15.

Norton, Y. H., Ceramies for the Artist Pottor. Reading, 1965.

Parmolee, Cullen W., Geramie Clazese Chicago, 1951.

Poor, Henry Varmum, 1 Book of Potterre Englewood Cliffs, 1958.

Ramsay, John. Amoricen Potters and Pottery, Clinton, 1939.

Rhodes, Daniol. Oley and Glezes for tine Pottor, Philedelphia, 1957.

Rhodes, Daniel. Stoneware and Porceleln. Philadelinhia, 1959.

Sandere, Herbert. Sunget Cerandes Book, Menlo Park, 1955.

Trevor, Henry. Pottery Sterebr-Stepe New York, 1946.

Turoff, Muriel Pargh. Hoe to Kalo Pottery and Other Ceramic Ware. Now York, 2949.

Untraent, Oppi. "The Bnduring Art of Huada, " Oraft Eorizons, XXI (November, December, 1961), 18-19.

Wandres, John 7. "The Byron Tenple Pottery," Ceramtes Honthly, 15 (December, 2967), 19-27.

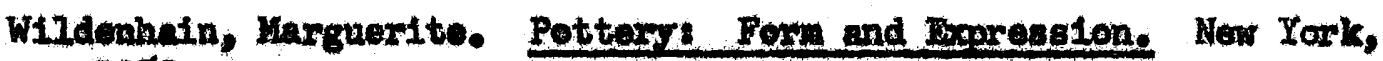
2959.

Wililans, Jonathan. "The Southern Appelachanians," Oraft Horizong XVII (June, 1966), 35-68. 
APPENDIX 


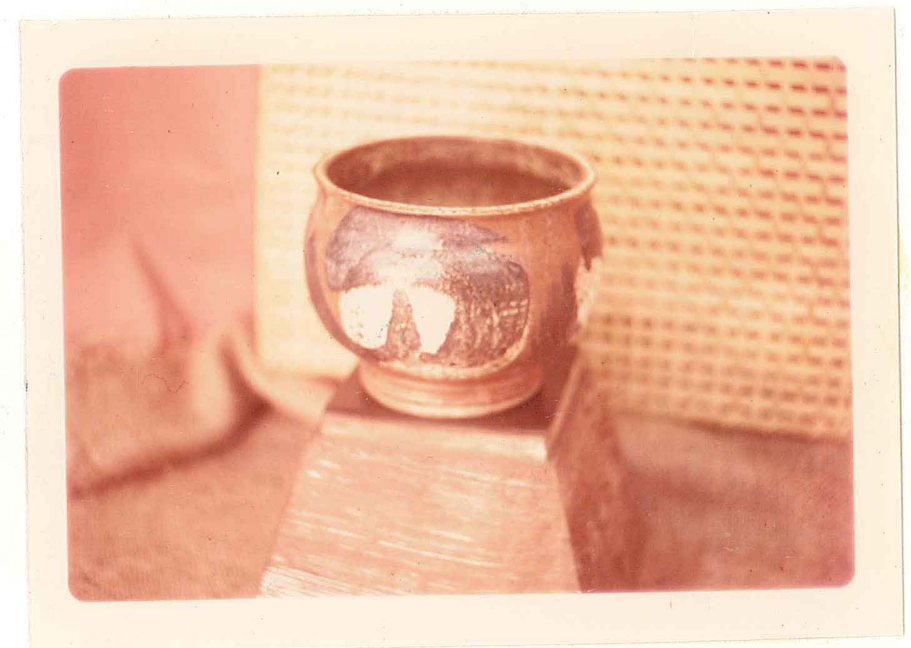

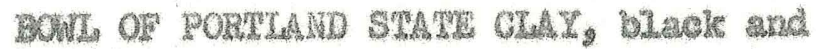
wht engobe Trensparent Grey Met alaze, mued to ceone terom (reduction) 
CONE TEN IMOOBES AND GLAZDS FOR REDUCTION FTRDNO

The basic materials used in engobes for cone ten reduction firing are the same as those used for cone six oxclation firing3 both temperatures are stoneware temperatures. However, the oxides are not always the same. Noither do they act in the sane way in this different atmosphere. The glases mat alwo be changed to fit cone ten reduction firing, and the selection of ohomiteals must be watchod wo that none have an adverse effect on the oxtdes uded in the engobes.

The dificulty in obtaining a good bleok has been explained. While this color presents a problem at cone alx it is an even greater one at oone tan. The usual formulas turn blue or brom, se the epeolal mix explained on page 16 was used in the following formule for cone ten reduction engobes. This black workad beautifully on a muber of pots that I fired in reduction, and It seamed to wall worth the extre effort involved.

\author{
Cone Ten Black Bingobe \\ 500 ga base engobe \\ 50 gm Portland State Clay \\ 100-125 ee black oxides (spectal formula)
}

On the following pages are given two bright glazes. and two send-mat glazes for cone ten reduction firing. These were tested and then used on a muber of engobed pots with very satisfactory results. 
TWO BRIGHR GLAZES FOR CONE 10 REDUCTION FIRINO

\begin{tabular}{lr}
\multicolumn{2}{c}{ "K" 2 Claze25 } \\
Kingman Folopar & 2016.0 \\
Whiting & 270.0 \\
Dolomite & 331.2 \\
Bariun Carbonate & 178.3 \\
Keolin & 185.4 \\
Opax & 297.9
\end{tabular}

"K" 2 Ginze is the bent general glase for clear effect over ongobes In reduction firing. The glase allows the colors of the ongobes to come through beautifully and at the seme time onhanees the cles bods not corered with ongobe.

\begin{tabular}{|c|c|}
\hline $\begin{array}{l}\text { Kingman Foldopar } \\
\text { Nopholine Syonite } \\
\text { Whituing } \\
\text { Dolomite } \\
\text { Berlum Carbonete } \\
\text { China Clay (Kaolin) } \\
\text { Mint }\end{array}$ & $\begin{array}{r}1120 \\
820 \\
300 \\
180 \\
390 \\
260 \\
120\end{array}$ \\
\hline
\end{tabular}

Oes Mat Giaze is only slightig mat, and because of this, It seems better to think of It as transparent, or sent-tranaparent rather than al a mat glaze. However, it does mute the colors more than really olear glaze.

TWO SEMI-HAT OLAZES FOR CONB 10, RBDUGTION FIRING

$\begin{array}{lr}\text { RHODES MACNESIA, CONE } 10 \text { REE } \\ \text { Kingman Feldepar } & 1800 \\ \text { Colomanite } & 520 \\ \text { Dolomito } & 280 \\ \text { Tele } & 600 \\ \text { China Clay } & 200 \\ \text { Flint } & 800\end{array}$

25 Frank A. Colson, "Oxide and Wax Resiat Decoration," Ceramice Nonthly, 15 (February, 2967), 20-23.

26 IBID., Pp. 20-23.

27 Dantel Rhodes, Notes, Dittoed Sheet, Portland State College. 
This glaze has a slightly milkg appearance with a tint of blue. It allows colors to show well, and is generally gocd glase. BALL'S TRANS GRAT MAT CONE 9-10 REDUUCTION FIRINO 28

$\begin{array}{lr}\text { Bolomite } & 558 \\ \text { Nepheline Syent te } 2350 \\ \text { Whiting } & 300 \\ \text { Jaolin } & 822 \\ \text { Flint } & 460 \\ \text { Opax } & 110 \\ \text { Zine Oxide } & 80\end{array}$

This soft, smooth glaze is really excellent over ongobes and over the elay body as well.

28 Ball, p. 62, 